\title{
İyi ebeveyn, çocuğu için her zaman her şeyi yapan ebeveyn değildir: Algılanan Helikopter Ebeveyn Tutum Ölçeği (AHETÖ) geliştirme çalışması
}

\author{
A good parent is not always the parent who does everything, every time \\ for his/her child: A Study to Develop Helicopter Parent Attitude/s Scale \\ (HPAS)
}

Hasan Yllmaz ${ }^{1}$

\begin{abstract}
Makale Geçmişi
Geliş : 15 Ekim 2018

Düzeltme : 07 Kasım 2018

Kabul : 09 Kasım 2018

Çevrimiçi : 09 Kasım 2018
\end{abstract}

\section{Makale Türü}

Araștirma Makalesi

\section{Article History}

Received : 15 October 2018

Revised : 07 November 2018

Accepted : 09 November 2018

Online :09 November 2018

\section{Article Type}

Research Article

\begin{abstract}
Öz: Helikopter anne baba kavramının 30 yllık bir geçmiși vardır. Bu çocuk yetiștirme tutumu; anne babanın çocuğu üzerinde aşırı kontrol sağlama çabası, ortada somut sebepler bulunmasa dahi çocuğunun bașına gelebilecek herhangi olası bir zarar veya bașarısızlığ önlemek için abartıll bir telaş ve çocuğa ihtiyaçlarının ötesinde özveri ile kendini gösterir. Bu araştırmanın amacı, algılanan helikopter ebeveyn tutumunu; anne ve baba düzeyinde etik konular, güven-temel yașam, akademik yașam ve duygusal yașam boyutlarında ölçebilecek geçerli ve güvenilir bir araç üretmektir. Araştırmanın örneklemi 13-45 yaş grubundan 2020 katılımcıdan oluşmaktadır. Veriler üzerinde AFA, DFA ve iç tutarlık katsayıları hesaplanmış ayrıca uyum geçerliğini sınamak için korelasyon katsayıları bulunmuştur. Ölçeğin anne formunun ait uyum endeksleri; $\chi 2 / \mathrm{sd}=10,05, \mathrm{RMSEA}=0,07, \mathrm{SRMR}=0,054, \mathrm{CFI}=0,95, \mathrm{NFI}=0,94$, $\mathrm{NNFI}=0,94, \mathrm{GFI}=0,91, \mathrm{AGFI}=0,90$; baba formu için ise; $\chi 2 / \mathrm{sd}=5,51, \mathrm{RMSEA}=0,050, \mathrm{SRMR}=0,045$, $\mathrm{CFI}=0,96, \mathrm{NFI}=0,95, \mathrm{NNFI}=0,95, \mathrm{GFI}=0,95, \mathrm{AGFI}=0,94$ olarak hesaplanmıştır. İç tutarlık katsayıları .85 ve .83 'dür. Ayrıca iki ayrı araçla test edilen uyum geçerliliği verileri, her iki form ve dört boyut için yeterli bulunmuştur. Geliştirilen ölçek; araştırmacılar, eğitimciler, çocuk gelişimi uzmanları tarafından, ebeveynlerin anne ve baba düzeyinde helikopter tutumlarını saptayabilecek nitelikleri taşımaktadır.
\end{abstract}

Anahtar Kelimeler: Ebeveynlik, Helikopter anne-baba, Ölçek geliştirme.

Abstract: The concept of helicopter parents has a history of 30 years. This child growing attitude shows itself as effort of parents to gain control on their child, exaggerated hastiness to prevent any possible damage or failure that can be happen to their child even that there is no perceptible reasons and with self-denying beyond the child's needs. The aim of this research is to produce valid and reliable tool that can measure perceived parental attitude, ethical subjects at mother and father level, trust- basic life, academical life and emotional life dimensions. The sample of the study consisted of 2020 participants in the 13-45 age group. AFA, CFA and internal consistency coefficients were calculated on the data and correlation coefficients were found to test the compliance validity. Fit indices of mother form of scale was calculated as $\chi 2 / \mathrm{sd}=10,05, \mathrm{RMSEA}=0,07, \mathrm{SRMR}=0,054, \mathrm{CFI}=0,95, \mathrm{NFI}=0,94, \mathrm{NNFI}=0,94$, $\mathrm{GFI}=0,91, \mathrm{AGFI}=0,90$; and for the father form of scale was calculated as; $\chi 2 / \mathrm{sd}=5,51, \mathrm{RMSEA}=0,050$, $\mathrm{SRMR}=0,045, \mathrm{CFI}=0,96, \mathrm{NFI}=0,95, \mathrm{NNFI}=0,95, \mathrm{GFI}=0,95, \mathrm{AGFI}=0,94$. The internal consistency coefficients are .85 and .83 . In addition, the compliance validity data tested with two separate tools were found sufficient for both forms and four dimensions. Developed scale has the qualifications that can determine the helicopter attitudes of parents at mother and father level by researchers, educators, child development specialists.

Keywords: Parenting, Helicopter parent, Scale development 


\section{SUMMARY}

\section{Introduction}

The most important feature of the helicopter parents, who are accepted as one of the most important problems of today in terms of parental attitudes, is their expectation of high success from their children and dithyrambically making their children as the sole focus of their lives (Odenweller et al., 2014). Talking about their children at every opportunity, trying to fill up every moment of the child with activities, doing the things that their children can do for them and fulfilling their responsibilities for them, trying to solve their problems for the child, taking care of their school lives and problems of the child in the extent that it discomforts the teacher (Fingerman et al., 2012; Olson-Buchanan, 2014) are the most common behaviors among parents who have this attitude.

Children with a helicopter parent are more likely to experience anger, depression, and anxiety problems than their peers (Fischer et al. 2007; Schiffrin, 2014; Tully, 2017). Additionally, psychosomatic disorders are more common among these children than their normal peers (Reed et al., 2016; Schiffrin et al., 2014).

In recent years, in abroad, a great deal of research has been done on helicopter parental attitudes and tools have been developed to measure this attitude. In Turkey there has not a study conducted on this subject yet. In this context, the purpose of the present study is developing a measurement tool that will determine the overprotective and intervention characterized attitudes of the parents in the scope of parents, based on the perceptions of the children and adults, and also which can be used by especially school guidance teachers, child development and education experts, educators and researchers.

\section{Method}

Study group was formed by four age groups as 13-17, 18-23, 24-30 and 31-45. These age groups are based on developmental periods. For preadolescent period 13-17 age group, for adolescence period 18-23 age group, for emerging adulthood period 24-30 age group, and for adulthood period 31-45 age group were selected. The sample size of each age group was planned to be 500 people with approximately half male and half female subjects.

Two different scales were used in order to test the concordance validity of the Perceived Helicopter Parental Attitude Scale. The first of these scales was the Parental Relation Attitude Perception Scale developed by Çelik and Öziş (2016); the second is the Parental Attitude Scale (PAS) developed by Lamborn et al. (1991).

The conformity of the data for factor analysis was analyzed with Kaiser-Meyer-Olkin (KMO) coefficient and Barlett Sphericity test. Factor analysis was performed in order to determine the construct validity of the scale and to determine and sizing the factor loads of the items. For this purpose, factor loads of Exploratory Factor Analysis (EFA); factor loads of the Confirmatory Factor Analysis (CFA) and the factor loads 
estimated by CFA were calculated. Cronbach Alpha ( $\alpha$ ), Guttman Split-half, Spearman-Brown reliability coefficients were calculated for the reliability analysis of the scale. In order to test the concordance validity, the correlations between Parental Relationship Attitude Scale, Parental Attitude Scale and Perceived Helicopter Parental Attitude Scales were looked.

\section{Findings:}

When starring factor analysis, Kaiser-Meyer-Olkin (KMO) coefficient was found as 0.89 and Barlett's value as $8409.743(\mathrm{p}<.000)$, which showed that data were in accordance with EFA.

In this study, Varimax which is one of the vertical rotation analyses was used and it was decided to have a 4-factor structure with an eigenvalue of 1 and a variance of more than 5\%. Four items which are overlapping and factor load value was lower than .32 were removed. The remaining 21 items explain $42.8 \%$ of the total variance. In the naming of these four sub-dimensions, the content of the items collected in the factors was taken into consideration. The factor loads of 6 items in the dimension of helicoptering on ethical and moral issues (HEM) varied between .81 and .63; factor loads of 5 items in helicoptering in academic / school life issues (HASL) varied between .75 and .64; factor loads of 6 items in helicoptering in basic confidence and life skills (HBCLS) varied between .82 and .59 and factor loads of 4 items in helicoptering in emotionalpersonal life (HEPL) varied between .75 and .54 .

Chi-square (X2), one of the CFA conformity indices, was found 10,05. In large samples, the increase in sd also causes problems in the evaluation of conformity. In this case, other conformity indices can be used to decide. In the present research, RMSEA was found as 0.07; CFI as 0.95; NFI as 0.94 and the NNFI value of and the non-standardized conformity index was found to be 0.94 . All these values show good conformity. Furthermore, GFI showing the overall covariance amount between the observed variables exceeding 0.90; calculation of adjusted goodness of conformity index, AGFI as 0.90 ; and the calculation square root of standardized mean errors, the SRMR value as 0.05 are a sign of good conformity. While the conformity indices were not generally consistent with the model data according to the $\chi^{2} / \mathrm{sd}$ index, model presents good conformity with data in terms of CFI, NFI, NNFI, SRMR and RMSEA values. Considering that the $\chi 2 /$ sd ratio is affected by the sample, the model shows a generally good conformity with data. In other words, it can be said that the model is validated, and the structure validity is ensured.

In addition to CFA, concordance and divergent validity studies were included in the study to examine the construct validity of the scale of the Perceived Helicopter Mother (HM).

Since the internal consistency (Cronbach's Alpha) and composite reliability of the helicopter mother scale are higher than .70 , it can be said that the helicopter mother scale has enough reliability level in terms of internal consistency. 
All the analyses described above were conducted for the father form of the helicopter parental scale and similar results were obtained.

The Parental Relationship Attitude Scale developed by Çelik and Öziş (2016) and the Parental Attitude Scale developed by Lamborn et al. (1991) and adapted to Turkish by Yllmaz (2000) were used to test the concordance validity of the developed Perceived Helicopter Parenting Attitude Scale. A correlation between .75 and .93 was observed between the relevant dimensions of both scales and mother and father forms of the helicopter parenting attitude scale.

\section{Discussion and Suggestions}

Although there has been a great deal of research on parental attitudes in Turkey, no research has been conducted on helicopter attitude. In the research of general parental attitudes, "loose of free attitude" or "strict discipline" issues were taken as dimensions, yet these researches are far from explaining helicopter parenting attitudes.

Developed Helicopter Parental Attitude Scale is the first study in this field. Naturally it needs to be criticized and developed. It is hoped that this study will at least open the discussion of helicopter parental attitudes in Turkey on a scientific platform.

The scale developed meets many statistical requirements. All conformity indices except one were enough and provided enough validity. Testing of the scale in different samples can provide more reliable results. Using the scale developed, various dimensions and results of the helicopter parenting can be revealed. For example, the relationship between the concepts of psychopathology, or positive psychology and the helicopter attitude can be studied. 


\section{GİRIŞ}

Psikoterapist Haim Ginott'un 1969 yllında ortaya attığı bir kavram olan "Helikopter Ebeveyn”, küçük bir çocuğun annesini bu şekilde tanımlaması sonucu ortaya çıkmıştır (Padilla-Walker ve Nelson, 2012). Ebeveyn tutumları konusunda günümüzün en önemli sorunları arasında kabul edilen helikopter anne babaların en belirgin özelliği çocuklarından yüksek başarı beklemeleri ve abartılı olarak çocuklarını hayatlarının yegâne ilgi odağı yapmalarıdır (Odenweller, BoothButterfield ve Weber, 2014). Genellikle tek veya az çocuklu ailelerde gözlenen bu tutuma sahip anne babalar, sürekli çocuklarının bir şeylerini eksik yapmış olabilme ihtimali üzerine odaklandıklarından bu durumun sonucu olarak kayg1 düzeyleri yüksektir (Stewart, Stewart ve Campbell, 2001; Kalkan ve Odac1, 2007; Gui ve Koropeckyj-Cox, 2016).

Helikopter ebeveyn tutumu son çeyrek yüzyılda her kültürde artı̧̧ göstermekte ve bu duruma sosyoekonomik düzeyi ortalamanın üzerinde olan ailelerde daha sık rastlanmaktadır (Kwon, Yoo ve De Gagne, 2017). Asya ve Amerika toplumlarının karşılaştırılmasını içeren araştırmalarda bu fark belirgin şekilde gözlenmiştir (Kwon ve Bingham, 2016). Her firsatta çocuklarından söz etme, çocuğun her anını etkinliklerle doldurmaya çalışma, çocuğun yapabileceği işleri ve sorumlulukları onun yerine yapma, sorunları çocuğun yerine çözmeye çalışma, çocuğun okul hayatı ve problemleri ile öğretmene rahatsızlık verecek ölçüde ilgilenme (Fingerman, Cheng, Wesselmann, Zarit, Furstenberg ve Birditt, 2012; Bradley-Geist ve Olson-Buchanan, 2014) bu tutuma sahip ebeveynlerde en sık gözlenen davranışlardır. Helikopter anne babalar başarı odaklıdır ve çocuğun okul hayatı başta olmak üzere her anına müdahale etmektedir (Kwon, Yoo ve Bingham, 2016; Schiffrin ve Miriam, 2017). Bu ailelerde çocuğun kendi inisiyatif ve istekleri ya çok az dikkate alınmakta ya da hiç dikkate alınmamaktadır (Hesse, Mikkelson ve Saracco, 2017). Dikkatle incelendiğinde helikopter anne babaların ebeveynlik davranışlarının altında kendi egoları bulunmaktadir (Odenweller vd., 2014).

Anne babaların çocukları ile ilgili konularda kullandıkları kelimeler de helikopter ebeveyn tutumuna sahip oldukları konusunda ip uçları içermektedir (Segrin, Woszidlo, Givertz, Bauer, Murphy, 2012). Bu tür ebeveynler genellikle çocuklarının adına konuşmayı; "bugün çok çalıştık", "bugün biraz hastaydık” gibi, cümlelerinde çoğul özne kullanmayı tercih etmektedir (Kelly vd., 2017).

Helikopter ebeveyne sahip çocuklar, öfke nöbetleri, depresyon ve kayg1 sorunlarını akranlarına oranla daha sık yaşamaktadır (Fischer, Forthun, Pidcock ve Dowd, 2007; Schiffrin, 2014; Tully, 2017). Bununla birlikte bu çocuklarda psikosomatik rahatsızlıklara normal akranlarından daha sık rastlanmıştır (Reed, Duncan, Lucier-Greer, Fixelle ve Ferraro, 2016; Schiffrin vd., 2014). Sosyal 
yaşamda da seçim yapma ve karar verme güçlükleri (Farley ve Kim-Spoon, 2014; Milita ve Bunch, 2017), anne babadan farklılaşamama ve bağlanma sorunları anlamlı düzeyde daha sı gözlenmiştir (Van Ingen, Freiheit, Steinfeldt ve Roberts, 2015; Conover ve Daiute, 2017).

Algılanan anne baba tutumları ölçülerek yetişkinler üzerinde yapılan araştırmalarda da çocukluğunda helikopter ebeveyn tutumu ile büyütülen bireylerde, daha fazla sağlik problemi (Nelson, Padilla-Walker ve Nielson, 2015; McGinley, 2018) gözlenmiştir. Araştırmacılar bu durumu helikopter ebeveynlerin çocuklarının sağlı̆̆ı konusunda gereğinden fazla endişelenmelerine ve sağlıklı çocuk büyütme kaygısı ile sağlıksız beslenme ve ilaç kullanma tutumlarına bağlamışlardır. Benzer bir araştırmada ise; helikopter anne babaya sahip bireylerin bencilliğe, egosantrik düşünceye narsis kişilik özelliğine daha yakın oldukları saptanmıştır (Findley ve Ojanen, 2013). Araştırmacılar bu durumu; çocuğun anne babalarından, "her şeye hakkı olduğu” mesajını alarak büyümeleri ile açıklamıslardır. Helikopter ebeveynin çocuklarının ileriki yaşamlarında daha fazla duygusal sorunlar yaşadıkları da rapor edilmiştir (Schiffrin vd., 2014; Kouros, Pruitt, Ekas, Kiriaki ve Sunderland, 2017). Araştırmacılar bu durumu, helikopter ebeveynlerin çocuklarının duygularını yaşamaya da müdahale etmeleri ve bu durumun sonucu olarak çocukların duygularını kontrol etmeyi öğrenemeden büyümeleri ile açıklamışlardır (LeMoyne ve Buchanan, 2011). Helikopter ebeveyn tutumu ile büyüyen çocukların yetişkin yaşamında “tolerans eşiğinin” de düşük olduğu gözlenmiştir (Ungar, 2009). Uyum sağlama (Nelson vd. 2015), baş etme ve mücadele etme becerileri yeterince gelişmediği için küçük sorunlar karşısında bile büyük yıkımlar yaşayabilmektedirler (Ungar, 2009; McGinley, 2018). Yapılan bir araştırmada bu durumun, psikotik ilaçlar kullanma yatkınlı̆̆ı ile ilişkili olduğu saptanmıştır. Aynı araştırmada bu bireylerin dinlenme ve eğlenme amaçlı ilaç kullanma alışkanlıklarının bulunduğu da rapor edilmiştir (Tully, 2017). Helikopter ebeveyn tutumu ile büyütülen çocukların yetişkinlikte hayatlarını kontrol etme ve yönetme konusunda da daha fazla zorluk çektikleri saptanmıştır (McGinley, 2018). Araştırmacılar bu durumu; helikopter ebeveynlerin çocuklarına yeterli serbest zaman firsatı tanımamalarına, çocuğun çevresini gereğinden fazla sınırlandırmalarına ve zamanı kullanma konusunda söz hakkı vermemelerine bağlamışlardır. Benzer bir araştırmada (Moilanen ve Manuel, 2017), helikopter ebeveynlerle büyümüş yetişkinlerin başarllı olmak için gereken zihinsel kontrol ve motivasyon düzeyleri de düşük bulunmuştur (Conover ve Daiute, 2017). Bu bireylerde işlerini erteleme eğilimine daha sık rastlanmış ve başarı için gereken girişimcilik ile motivasyon düzeylerinin, diğer ebeveyn tutumları ile büyütülen çocuklara kıyasla anlamlı düzeyde farklı olduğu gözlenmiştir.

Yurtdışında son yıllarda helikopter ebeveyn tutumları konusunda çok sayıda araştırma yapılmış ve bu tutumu ölçen araçlar geliştirilmiştir (Love, 2016; BaoChun, 2016; LeMoyne ve Buchanan, 2011; 
Odenweller, Booth-Butterfield ve Weber, 2014). Türkiyede ise henüz bu konuda yapılmış bir araştırmaya rastlanmamıstır. Ebeveyn tutumlarının kültürel yapı ile çok yakından ilişkili olmasından dolayı, yurtdışında geliştirilmiş bir ölçeğin Türkçeye uyarlanması anlayışı benimsenmemiş, bunun yerine Türk kültürünü dikkate alan özgün bir araç geliştirme yaklaşımı benimsenmiştir.

Bu bağlamda çalışmanın amacı, özellikle okul rehber öğretmenlerinin, çocuk gelişimi ve eğitimi uzmanlarının, eğitimci ve araştırmacıların kullanabilecekleri; ebeveynlerin aşırı koruma ve müdahaleleri ile karakterize olmuş tutumlarını; anne ve baba boyutunda, çocukların ve yetişkinlerin algılarına dayalı olarak belirleyecek bir ölçme aracı geliştirmektir.

\section{YÖNTEM}

\section{Çalışma Grubu}

Çalışma grubu 13-17, 18-23; 24-30 ve 31-45 şeklinde dört yaş grubu belirlenerek oluşturulmuştur. Bu yaş gruplarının belirlenmesinde gelişim dönemleri temel alınmıştır. 13-17 yaş grubu için erinlik ya da ön ergenlik, 18-23 için ergenlik, 24-30 için beliren yetişkinlik ve 31-45 için yetişkinlik dönemleridir. 2020 kişilik örneklem büyüklüğü, yaklaşık olarak yarısı erkek, yarısı kadın ve her yaş grubunda 500 katılımcı olacak şekilde planlanmıştır. Araştırmada yaş değişkenine ilişkin aralığın 1345 olması, örneklem büyüklügünü belirlemede rol oynamıştır. Çalışmaya katılımda gönüllülük ilkesi ön koşul olarak belirlenmiş, ayrıca 13-17 yaş grubuna uygulama yapılabilmesi için ilgili il milli eğitim müdürlüğünden, 18-23 yaş grubuna uygulama yapılabilmesi için de fakülte dekanlığından izin alınmıştır. 24-30 ve 31-45 yaş gruplarının dağglımında da eğitim seviyesi değişkeni esas alınmış; temel eğitim, orta öğretim ve yükseköğretim seviyelerine dağılımların dengeli olmasına dikkat edilmiştir. $\mathrm{Bu}$ planlamaya uygun olarak oluşturulan çalışma grubuna ilişkin sayısal bilgiler Tablo 1'de gösterilmiştir.

Tablo 1. Çalışma grubunun yaş ve cinsiyetlere dağıllımı

\begin{tabular}{|c|c|c|c|c|c|c|c|c|c|c|}
\hline & \multicolumn{2}{|c|}{$13-17$} & \multicolumn{2}{|c|}{$18-23$} & \multicolumn{2}{|c|}{$24-30$} & \multicolumn{2}{|c|}{$31-45$} & \multicolumn{2}{|c|}{ Toplam } \\
\hline & $\mathrm{N}$ & $\%$ & $\mathrm{~N}$ & $\%$ & $\mathrm{~N}$ & $\%$ & $\mathrm{~N}$ & $\%$ & $\mathrm{~N}$ & $\%$ \\
\hline Kadin & 286 & 53.3 & 229 & 45.1 & 241 & 50.3 & 243 & 49.0 & 999 & 49.5 \\
\hline Erkek & 251 & 46.7 & 279 & 54.9 & 238 & 49.7 & 253 & 51.0 & 1021 & 50.5 \\
\hline Toplam & 537 & 100 & 508 & 100.0 & 479 & 100.0 & 496 & 100.0 & 2020 & 100.0 \\
\hline
\end{tabular}

\section{Bilgi Toplama Araçları}

Geliştirilen “Algilanan Helikopter Ebeveyn Tutum Ölçeğì”nin uyum geçerliğini sınamak amaciyla 2 ayrı ölçek kullanılmıştır. Bu ölçeklerden ilki, Çelik ve Öziş (2016) tarafindan geliştirilen Ebeveyn İlişki Tutumu Algısı Ölçeğidir. Ölçek anne ve baba tutumlarını beş boyutta ölçmektedir. Bu 
boyutlar; otoriter, ilgisiz, koruyucu, demokratik, bağımlı şeklinde isimlendirilmiştir. 37 maddeden oluşan ölçeğin faktör yükleri, anne formunda .56 ile .89 , baba formunda ise .53 ile .82 arasinda değişmektedir. Ölçeğin iç tutarlık katsayıları ise, .80 ve .95 olarak bildirilmiştir.

Alg1lanan Helikopter Ebeveyn Tutum Ölçeğinin uyum geçerliğinin sınandığ1 ikinci araç, Lamborn ve arkadaşları (1991) tarafindan geliştirilen Anne Baba Tutum Ölçeği (ABTÖ)'dir. Ölçek; Kabul/İlgi, Denetleme ve psikolojik özerklik adı altında üç boyuta sahiptir. Yılmaz (2000) tarafından Türkçeye uyarlanan ölçek; kabul/ilgi ve denetleme boyutları altında, demokratik, ihmalkâr, otoriter ve hoşgörülü anne baba yaklaşımlarını ölçmeyi amaçlamaktadır. İlköğretimi lise ve üniversite öğrenci grupları üzerinde yapılan çalışmada, ölçeğin iç tutarlık katsayıları .65 ile .88 arasında değişen değerlerde hesaplanmıştır.

\section{Analiz Yöntemleri}

Faktör analizi için verilerin uygunluğu Kaiser-Meyer-Olkin (KMO) katsayısı ve Barlett Sphericity testi ile sınanmıştır. Ölçeğin yap1 geçerliliğini ortaya koymak ve maddelerin faktör yüklerini belirlemek ve boyutlandırabilmek amacıyla faktör analizi yapılmıştır. Bu amaçla Açımlayıcı Faktör Analizine (AFA) ait faktör yükleri; Doğrulayıc1 Faktör Analizine (DFA) ait faktör yükleri ve DFA ile tahminlenen faktör yükleri hesaplanmıştır. Ölçeğin güvenirlik analizleri için Cronbach Alfa $(\alpha)$, Guttman Split-haf, Spearman-Brown güvenirlik katsayıları hesaplanmıştır. Uyum geçerliğini sınmak amacıyla, Ebeveyn İlişki Tutumu Algısı Ölçeği ve Anne Baba Tutum Ölçeği ile Algılanan Helikopter Ebeveyn Tutum Ölçekleri arasındaki korelasyona bakılmıştır. Analiz yöntemlerinin belirlenmesinde ilgili literatürden yararlanılmıştır (MacCallum, Widaman, Preacher ve Hong, 2001; Yaşlığlu, 2017).

\section{Ölçeğin Yapısı}

Algılanan Helikopter Ebeveyn Tutum Ölçeğinin geliştirilmesinin iki temel dayanağı vardır. Bunlardan ilki yazarın 30 yılı aşkın anne-baba eğitimi ve aile danışmanlığı yaşantılarından edindiği mesleki birikimidir. İkincisi, bu konuda yurtdışında yayınlanan literatürde yer alan benzer amaçla geliştirilmiş ölçme araçlarıdır (Love, 2016; BaoChun, 2016; LeMoyne ve Buchanan, 2011; Odenweller, Booth-Butterfield ve Weber, 2014).

Anne-baba eğitimi ve aile danışmanlığı çalışmalarında, çocuklarını kendi uzantıları gibi gören bazı anne babaların davranışları dikkat çekmiştir. $\mathrm{Bu}$ anne babalar özellikle çocuklarının "farklılaşmasına" müsaade etmeyerek onların "birey" olmalarına engel olduklarının farkında 
değillerdi. Daha yakından incelendiğinde, çocuklarına aşırı şekilde odaklanmış oldukları, onların yapabileceği işleri dahi onların yerine yaptıkları, onlara ilişkin tüm kararları kendilerinin aldığı ve adeta bir antrenör gibi davrandıkları görüldü. Geliştirilen ölçeğin madde havuzunun kaynağı, bu tespitlere ilişkin notlar ve yurtdışında yapılan araştırmalardan elde edilen bilgilerdir (Love, 2016; BaoChun, 2016; LeMoyne ve Buchanan, 2011; Odenweller, Booth-Butterfield ve Weber, 2014).

Başlangıçta helikopter ebeveyn tutumunu yansıtan 118 madde hazırlanmış, uzman görüşü ve literatür desteği ile madde sayısı 60'a düşürülmüştür. Uzman görüşünün değerlendirilmesinde, Davis (1992)'nin önerdiği yöntem benimsenmiş, uzman görüşleri; (a) “uygun”, (b) “madde hafifçe gözden geçirilmeli”, (c) "madde ciddi olarak gözden geçirilmeli” ve (d) "madde uygun değil”" şeklinde dörtlü derecelendirmeye tabi tutulmuştur. Toplanan görüşlerden (a) ve (b) seçeneğini işaretleyen uzmanların sayısı toplam uzman sayısına bölünerek maddeye ilişkin “kapsam geçerlik indeksı" elde edilmiş, ölçüt olarak .80 düzeyi kabul edilmiştir. Bununla eş zamanlı olarak, iki ayrı ortaokulda 6. ve 7. sınıf öğrencilerinden oluşan 216 kişilik bir gruba; "anne ve babasının aşırı ilgisinden ve üzerine çok düşmesinden rahatsız olanlar var mı?” sorusu sorulmuş, cevabı "evet" olan 74 öğrenciye, "anne ve babanızın hangi davranışları sizi rahatsız ediyor” başlığını taşıyan serbest anlatımlı bir kompozisyon yazdırılmıştır. Kompozisyonlar, iki tanesi okul öncesi öğretmenli anabilim dalında profesör, bir tanesi çocuk psikolojisi alanında 20 yıllık doktoralı uzman üç kişilik grup tarafindan değerlendirilmiş ve ortak olan 38 madde tespit edilmiştir $(r=.94)$. Uzman grubun tespitinde, bilim dalları ve ulaşılabilirlik kriterleri kullanılmıştır.

Üçüncü aşamada kompozisyon içeriklerinden çıkartılan 38 madde ile, literatür ve mesleki deneyim kaynaklı 60 madde içinden ortak olan ve örtüşenler belirlenerek 25 maddelik ilk form oluşturulmuştur. Ortaya çıkan ilk formda yer alan maddeler şu şekildedir:

1- Her gün giyeceğim kiyafetleri seçmek ister.

2- Ne zaman üzgün olsam israrla "neyin var" diye sorar.

3- Arkadaşlarımla oyun oynarken oyunumuza müdahale etmeden duramaz.

4- Akşam eve geldiğimde ilk soruları genellikle okul hayatım ile ilgili olur.

5- Dünyanın ve çevremizin kötü insanlarla dolu olduğuna inanır.

6-Okula başladığım günlerde saatlerce okul dışında veya evin önünde beni bekler

7- Suratımın asık olmasına hiç katlanamaz.

8- Büyüdüğümü bir türlü kabul etmek istemez.

9- Sınav sonuçlarımın açıklanacağı zamanı sabırsızlıkla bekler.

10- Çok sik nasihat eder.

11- Benim özel bir hayatım olabileceğini kabul etmek istemez.

12- Hasta olmamdan çok korkar.

13- Ne zaman arkadaşlarımla tartışsam hep beni savunur.

14- Okul notlarım için benden daha çok o kaygılanır.

15- Yüz kızartıcı bir davranışta bulunmamam konusunda çok nasihat eder.

16- Parkta ve sokakta gezerken asla elimi birakmak istemez.

17- Duygularımı her zaman merak eder.

18- Arkadaş seçimlerimde hep onun onayını almam gerektiğini söyler. 
19- Öğretmenim ile çok s1k görüşmek ister.

20- Kötü huy ve alışkanlıklar edinmemden çok korkar.

21-Bana yemek yedirmek için arkamdan koșturur.

22- Çantamın içini ve ceplerimi sık sık kurcalamaktan hoşlanır.

23- Karşı cinsten bir arkadaşımın olması ihtimali onu endişelendirir.

24- Okul ödevlerim için benden çok o çaba gösterir.

25- Mükemmel bir insan olmamı ister.

\section{Öngörülen Alt Boyutların belirlenmesi}

25 maddeden oluşan ve geçerlik güvenirlik analizleri yapılması için uygulamaya hazırlanan helikopter ebeveyn ölçeğinin beklenen (hipotez olarak kabul edilen) alt boyutları, bu konusundaki literatüre uygun olarak saptanmıştır (Love, 2016; BaoChun, 2016; LeMoyne ve Buchanan, 2011; Odenweller, Booth-Butterfield ve Weber, 2014). Bu alt boyutlar, (1) Temel güven konusunda helikopter tutum (TGYBKH), (2) Duygusal-kişisel yaşam alanında helikopter tutum (DYKH), (3) Akademik yaşam alanında helikopter tutum (AOYKH) (4) Etik-ahlaki konularda helikopter tutum (EAK) şeklindedir. Ölçeğin derecelendirme kategorileri dörtlü likert tarzında; (1) Hiç böyle davranmaz, (2) Arada sırada böyle davranır, (3) Çoğu zaman böyle davranır ve (4) Hep böyle davranır şeklindedir

Ölçek; anne ve babaya ilişkin algılara ait ayrı ayrı bilgilerin toplanabilmesi için, cevaplayıcıların hem annesinin hem de babasının tutumunu işaretleyebileceği bir yapıda düzenlenmiştir. Bu yapının seçilmesindeki amaç, ölçeği kullanacak araştırmacı ve eğitimcilerin, anne ve baba tutumları arasındaki farklara dayalı veriler elde edebilmesini sağlamaktır.

\section{Ölçeğin Geçerlik Güvenirlik Çalışmalarına İlişkin Uygulamalar}

Ölçek dört ayrı gruba, 2 Mayıs-1 Haziran 2018 tarih aralığında uygulanmıştır. 13-17 yaş grubuna uygulama yapabilmek için ilgili milli eğitim müdürlüğünden dört okul için; 18-23 yaş grubuna uygulama yapabilmek için ilgili fakülteden izin alınmıştır. Diğer iki yaş gruplarına uygulama yapılırken, iki resmi, iki özel sektörde çalısanların yanında ev hanımı olan bir grup seçilmiştir. Uygulama yapacak olan ekibe yarım günlük bir eğitim verilmiş ve katılım konusunda deneklerden gönüllük beyanı alınmıştır.

\section{Ön Analizler}

Gelişmiş istatistiksel tekniklerden biri olan DFA ve AFA analizlerini yapabilmek için bazı varsayımlar yerine getirilmelidir (Çokluk Vd., 2012). İlk olarak, istatiksel analiz için örneklem büyüklügünün uygunluğu kontrol edilmiş ve araştırmanın örnekleminin, ölçekteki her bir madde sayısının en az beş katı olması şartını sağladığı görülmüştür (Büyüköztürk, 2010). Örneklemden elde edilen verilerde kayıp değerlerin bulunup bulunmadığı saptandıktan sonra, çok değişkenli uç değer 
olup olmadığının tespit edilmesi için Mahalonobis uzaklığı hesaplanmış ve örneklemden önemli miktarda sapma gösteren 45 adet çok yönlü uç değer tespit edilerek analizden çıkartılmıstır (Büyüköztürk, 2010). Tek değişkenli uç değer için standart $Z$ değerleri incelenmiş ve sınır değerleri olan $(-3,+3)$ aralı̆̆ı dışında kalan 42 uç değer saptanarak analizden çıkartılmıştır (MacCallum, Widaman, Preacher ve Hong, 2001; Büyüköztürk, 2010; Yaşlığlu, 2017). Aynı zamanda, doğrusallık, tek değişkenli ve çok değişkenli normallik varsayımları incelenmiş olup, değişkenler arasında doğrusal bir ilişki olduğu ve verilerin hem tek hem de çok değişkenli normal dağglım gösterdiği saptanmıştır. Tek değişkenli normal dağılım için çarpıklık ve basıklık katsayılarının \pm 1 aralığında olması; ortalama, mod ve medyanın birbirine yakın değerler vermesi şartları da kontrol edilmiş ve çok değişkenli normal dağ̣lım için Barletts küresellik testi incelenmiştir. Değişkenler arasında çoklu bağlantılılık problemi olup olmadığının incelenmesi amacıyla değişkenler arasındaki korelasyonlar hesaplanmış ve sonuçlar çoklu bağlantı probleminin olmadığına işaret etmiştir. Model verilerinin uyumluluğunun geliştirilmesi için önerilen değişiklikler arasında, teorik olarak mümkün olan $\chi^{2}$ değerinde önemli azalmaya yol açan maksimum ölçekteki üç madde çifti arasında değişiklik yapılmıştır (Jöreskog ve Sörbom, 1993). Ön analize ilişkin değerler Tablo 2'de gösterilmiştir.

Tablo 2. Ölçeklere ait betimsel istatistik değerleri

\begin{tabular}{lrrr}
\hline & ANNE & BABA & TOPLAM \\
\hline Ortalama & 48.3422 & 42.4801 & 45.4113 \\
Medyan & 48.0000 & 42.0000 & 45.5000 \\
Mod & 49.00 & 38.00 & 44.00 \\
Standart Sapma & 10.59192 & 9.74744 & 8.87162 \\
Çarpılık & .184 & .164 & .117 \\
Çarp1klı̆̆1n Standart Hatası & .058 & .058 & .058 \\
Basıklık & -.484 & -.405 & -.436 \\
Basıklığın Standart Hatası & .115 & .115 & .115 \\
Minimum & 23.00 & 21.00 & 22.50 \\
Maximum & 80.00 & 71.00 & 73.00 \\
\hline
\end{tabular}

\section{BULGULAR}

\section{Helikopter Anne Ölçeğine Ait Geçerlik Bulguları}

Verilerin faktör analizine uygunluğu Kaiser-Mayer-Olkin (KMO) katsayısı ve Barlet Testi ile incelenmiştir. KMO’nun 0.60'dan yüksek çıkması ve Barlett testinin anlamlı çıkması gerekmektedir (Büyüköztürk; 2010). Aksi taktirde analize devam edilemeyecektir. Faktör analizine başlarken verilerin uygunluğunu test etmek amacıyla yapılan Kaiser-Mayer-Olkin (KMO) katsayısı değeri 0,89 Bartlett's değeri ise 8409,743 ( $\mathrm{p}<.000)$ olarak çıkması verilerin AFA ya uygun olduğunu göstermektedir. 
Alan yazında, bir maddenin faktör yük değeri için asgari büyüklüğün .32 olması yönünde yaygın bir görüş vardır (MacCallum, Widaman, Preacher ve Hong, 2001; Büyüköztürk, 2010; Yaşlığlu, 2017). Buradan hareketle belirlenen kesme noktası .32 'dir. Bu çalışmada dik döndürme analizlerinden Varimax kullanılmış ve öz değerleri 1'in ve açıkladığı varyans \%5’in üzerinde olan 4 faktörlü yapıda olmasına karar verilmiştir. Faktör yük değeri .32'nin altında ve binişik-bulaşık olan 4 madde çıkartılmıştır. Kalan 21 madde toplam varyansın \%42,8’ini açıklamaktadır. Birden fazla boyuta giren madde saptanmamıştır.

Tablo 3. Algılanan Helikopter Anne Tutum Ölçeği maddelerinin faktörlere dağılımı

\begin{tabular}{|c|c|c|c|c|}
\hline Maddeler & 1. $\quad$ Boyut & 2. $\quad$ Boyut & 3. $\quad$ Boyut & 4. $\quad$ Boyut \\
\hline HA15 & .817 & & & \\
\hline HA 20 & .766 & & & \\
\hline HA 10 & .725 & & & \\
\hline HA 5 & .705 & & & \\
\hline HA 23 & .632 & & & \\
\hline HA 25 & .631 & & & \\
\hline HA 9 & & .753 & & \\
\hline HA 14 & & .739 & & \\
\hline HA 24 & & .704 & & \\
\hline HA 19 & & .691 & & \\
\hline HA 4 & & .641 & & \\
\hline HA 16 & & & .821 & \\
\hline HA 22 & & & .792 & \\
\hline HA 21 & & & .702 & \\
\hline HA 3 & & & .690 & \\
\hline HA 6 & & & .671 & \\
\hline HA 1 & & & .590 & \\
\hline HA 2 & & & & .759 \\
\hline HA 7 & & & & .720 \\
\hline HA 17 & & & & .693 \\
\hline HA 11 & & & & .543 \\
\hline
\end{tabular}

Birinci faktörde bulunan maddeler (M15- Yüz kızartıcı bir davranışta bulunmamam konusunda çok nasihat eder; M20- Kötü huy ve alışkanlıklar edinmemden çok korkar; M10- Çok sık nasihat eder; M5- Dünyanın ve çevremizin kötü insanlarla dolu olduğuna inanır; M23- Karşı cinsten bir arkadaşımın olması ihtimali onu endişelendirir ve M25- Mükemmel bir insan olmamı ister) daha çok annelerin etik ve ahlaki konulardaki çocuk yetiştirme yaklaşımını yansıttığı için, bu boyuta "etik ve ahlaki konularda helikopterlik (EAKH) ismi verilmiştir. Bu faktör altında toplanan maddeler annelerin çocuklarının ahlaki konulardaki davranışlarına karşı gösterdikleri tutum ve anlayışlarını yansıtmaktadır ve altı maddenin faktör yükleri .81 ile .63 arasında değişmektedir.

İkinci faktörde bulunan maddeler (M9- Sınav sonuçlarımın açıklanacağı zamanı sabırsılılkla bekler; M14- Okul notlarım için benden daha çok o kaygılanır; M24- Okul ödevlerim için benden çok o çaba gösterir; M19- Öğretmenim ile çok s1k görüşmek ister; M4- Akşam eve geldiğimde ilk sorular1 genellikle okul hayatım ile ilgili olur) daha çok annelerin çocuğun okul hayatı ve akademik yaşamı 
ile ilgili konularda sergilediği tutumu yansıttığı için, bu boyuta "akademik / okul yaşamı konularında helikopterlik (AOYKH) ismi verilmiştir. Bu boyutta yer alan 5 maddenin faktör yükleri .75 ile .64 arasında değişmektedir.

Tablo 4. Algılanan Helikopter Anne Tutum Ölçeği Faktörlerin açıkladıkları varyanslar

\begin{tabular}{lccc}
\hline FAKTÖRLER & Total & \% Açıkladikları varyans & Kümülatif varyans \% \\
\hline 1 & 5.470 & 26.047 & 26.047 \\
2 & 1.567 & 7.460 & 33.507 \\
3 & 1.433 & 6.824 & 40.331 \\
4 & 1.226 & 5.837 & 46.168 \\
\hline 5 & .991 & 4.718 & 50.885 \\
6 & .840 & 4.000 & 54.886 \\
7 & .824 & 3.925 & 58.810 \\
8 & .804 & 3.831 & 62.641 \\
9 & .774 & 3.686 & 66.327 \\
10 & .753 & 3.585 & 69.912 \\
11 & .733 & 3.490 & 73.402 \\
12 & .691 & 3.292 & 76.694 \\
13 & .662 & 3.154 & 79.848 \\
14 & .618 & 2.942 & 82.790 \\
15 & .588 & 2.802 & 85.592 \\
16 & .566 & 2.697 & 88.289 \\
17 & .544 & 2.589 & 90.878 \\
18 & .536 & 2.552 & 93.430 \\
19 & .499 & 2.378 & 95.808 \\
20 & .471 & 2.243 & 98.051 \\
21 & .409 & 1.949 & 100.000 \\
\hline
\end{tabular}

Üçüncü faktörde bulunan maddeler (M16- Parkta ve sokakta gezerken asla elimi bırakmak istemez; M22- Çantamın içini ve ceplerimi sık sık kurcalamaktan hoșlanır; M21-Bana yemek yedirmek için arkamdan koşturur; M3- Arkadaşlarımla oyun oynarken oyunumuza müdahale etmeden duramaz; M6-Okula başladığım günlerde saatlerce okul dışında veya evin önünde beni bekler; M1- Her gün giyeceğim kıyafetleri seçmek ister) daha çok annelerin çocuklarının temel yaşam becerileri konusuna ilişkin olduğu ve temel güven/güvensizlik ifade eden içerikler taşıdığından, bu boyuta "temel güven ve yaşam becerileri konusunda helikopterlik" (TGYBKH) ismi verilmiştir. Bu boyutta yer alan altı maddenin faktör yükleri .82 ile .59 arasında değişmektedir.

Dördüncü faktörde bulunan maddeler (M2- Ne zaman üzgün olsam 1srarla "neyin var" diye sorar; M7- Suratımın asık olmasına hiç katlanamaz; M17- Duygularımı her zaman merak eder; M11Benim özel bir hayatım olabileceğini kabul etmek istemez) daha çok annelerin çocuklarının 
duygusal yaşamına ve mahremiyet alanlarına ilişkin tutumlarını yansıttığı için, "duygusal-kişisel yaşam alanında helikopterlik” (DYKH) ismi verilmiştir. Dört maddeden oluşan boyutta faktör yükleri .75 ile .54 arasında değişmektedir.

\section{Helikopter Anne Ölçeğine Ait Doğrulayıcı Faktör Analizi}

Algılanan helikopter anne ölçeğinin doğrulayıcı faktör analizine ilişkin sonuçlar Şekil 1'de gösterilmiştir. Anlamlılık değeri olan $p$, beklenen kovaryans matrisi ile gözlenen kovaryans matrisi arasındaki farkın manidarllğı hakkında bilgi verir. DFA'de $p$ değerinin anlamlı olması beklenir (Çokluk, Şekercioğlu ve Büyüköztürk, 2010). Araştırmada $p=.000 ; p<.05$ olarak elde edilmiştir. Bu durum, beklenen kovaryans matrisi ile gözlenen kovaryans matrisi arasındaki farkın anlamlı olduğunu göstermektedir. Modele ilişkin uyumluluk indeksleri Tablo 5'de verilmiştir.

Tablo 5. Helikopter Anne doğrulayıcı faktör analizine ilişkin bulgular

\begin{tabular}{lccccccccc}
\hline$\chi^{2}$ & sd & $\chi^{2} /$ sd & RMSEA & SRMR & CFI & NFI & NNFI & GFI & AGFI \\
\hline 1860,74 & 185 & 10.05 & 0.07 & 0.054 & 0.95 & 0.94 & 0.94 & 0.91 & 0.90 \\
\hline
\end{tabular}

DFA'da öncelikle incelenmesi gereken uyumluluk indeksi Ki-kare $\left(\mathrm{X}^{2}\right)$ uyum istatistiğidir ve serbestlik derecesine olan oranı 3'ün altında olması mükemmel uyuma 5 ve altında olması iyi uyum olduğunu söyler (Kline, 2005). Bu oran 10,05 olarak bulunmuştur. Büyük örneklemlerde sd'nin büyümesi de uyumun değerlendirilmesinde sorunlar çıkarmaktadır. Diğer bir ifade ile sd arttıkça (DFA analizi sonucunda hesaplana $\mathrm{X}^{2}$ değeri iki kovaryans arasındaki uyum değerinin sd'nin bir eksiği ile çarpılmasıyla elde edilir.) $X^{2}$ ve sd oranı da artmaktadır. Örneklem büyüklüğü için 200 sayısının altında olan değerlerde oranın küçülmesine neden olmaktadır (Çokluk, Şekercioğlu ve Büyüköztürk, 2010). Bu durumda diğer uyum indekslerine bakılarak karar verilebilir.

RMSEA; hata karelerinin ortalamasının karekökü olup, modelin anlamlı olabilmesi için 0,05'den küçük olduğunda mükemmel uyum, 0,10'dan küçük olduğunda ise iyi uyum olduğunu söyler (Steiger, 1990). RMSEA değeri 0,07 olarak bulunmuştur ve iyi uyum göstermektedir.

CFI; model tarafindan tahmin edilen kovaryans matrisi ile sifir hipotezli modelin kovaryans matrisini karşılaştıran bir uyum indeksidir (Hooper, Coughlan ve Mullen, 2008). CFI 0 ile 1 arasında değissen değerler alır. 0.95 ile 1 arasında CFI değerine sahip bir modelin iyi uyum içinde olduğu, 0.90 ile 0.95 arasında CFI değerine sahip bir modelin kabul edilebilir uyum içinde olduğu söylenebilir (Hu ve Bentler, 1999). Araştırmanın 0.95 bulunan CFI değeri iyi uyumu gösterir. CFI 
indeksi günümüzde yapısal eşitlik modellerinde en yaygın olarak kullanılan uyum indeksidir (Fan, Thompson ve Wang, 1999).

NFI; normlaştırılmış uyum indeksi olup, CFI'ya alternatif olarak Bentler ve Bonett (1980) tarafindan geliştirilmiştir. Bu indeks varsayılan modelin temel ya da sıfir hipoteziyle olan uygunluğunu araştırır. NFI değeri 0,94 olarak elde edilmiştir ve iyi uyum olduğunu gösterir. Ayrıca normlaştırılmamış uyum indeksi olan NNFI değeri ise 0,94 olarak bulunmuştur ve iyi uyum olduğunu gösterir (Şehribanoğlu, 2005).

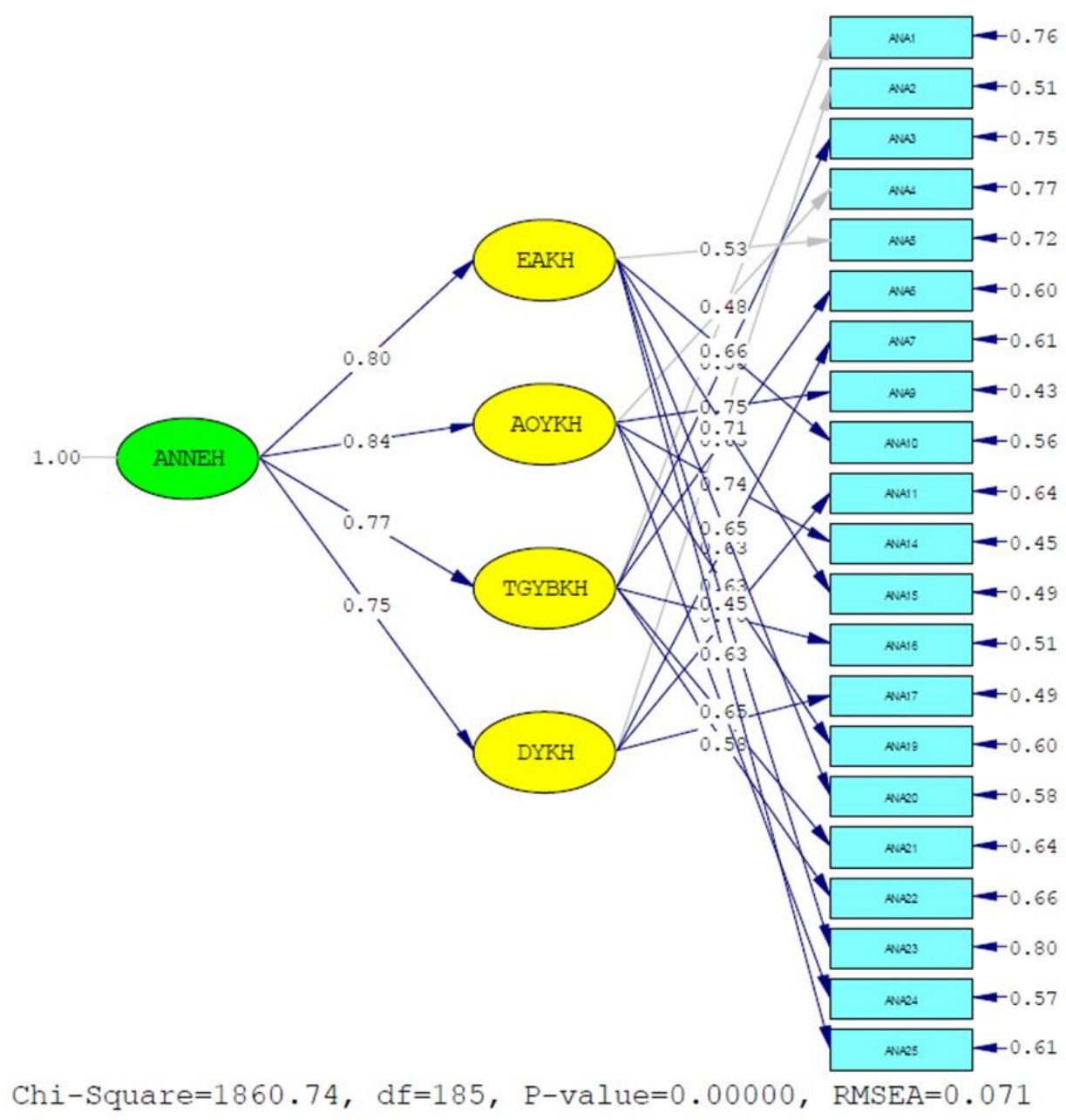

Şekil 1: Helikopter Anne Ölçeğine Ait Doğrulayıcı Faktör Analizi

GFI, varsayılan modelce hesaplanan gözlenen değişkenler arasındaki genel kovaryans miktarını gösterir. GFI değeri 0 ile 1 arasında değişir. GFI'nın 0.90’1 aşması iyi bir model göstergesi olarak alınmaktadır. Bu gözlenen değisskenler arasında yeterince kovaryansın hesaplandığı anlamına gelmektedir (Schumacker ve Lomax, 1996). GFI değeri 0,91 olarak elde edilmiştir ve iyi uyum olduğunu gösterir. AGFI ise düzenlenmiş uyum indeksidir bu değer ise 0,90 olarak elde edilmiştir ve iyi uyum göstermektedir. 
SRMR; standartlaştırılmış ortalama hataların kareköküdür. SRMR değeri 0'a yaklaştıkça modelin uyum iyiliği artar. Model, 0.05 'ten düşük bir SRMR değeri almışsa iyi uyum, 0.05 ile 0.08 arasında bir SRMR değeri almısssa kabul edilebilir uyum içerisindedir (Hu ve Bentler, 1999). Araştırmada bulunan $0.05^{\prime}$ lik değer iyi uyumu göstermektedir.

Uyum indeksleri genel olarak değerlendirildiğinde $\chi^{2} / \mathrm{sd}$ indeksine göre model veriye uyum göstermez iken, CFI, NFI, NNFI, SRMR ve RMSEA değerleri açısından model veriye iyi uyum göstermektedir. $\chi^{2} /$ sd oranının örneklemden etkilendiği göz önüne alınırsa, genel olarak değerlendirildiğinde model veriye iyi uyum göstermektedir. Diğer bir ifade ile modelin doğrulandığ1 ve yapı geçerliliğinin sağlandığı söylenebilir.

\section{Yakınsak ve Iraksak Geçerlik}

Araştırmada Algılanan Helikopter Anne (HA) ölçeğinin yapı geçerliğini incelemek için DFA'ya ek olarak, yakınsak ve ıraksak geçerlik çalışmalarına da yer verilmiştir. DFA'dan elde edilen faktör yüklerinin yeterince yüksek olması, ölçeğin yakınsak geçerliğinin sağlandığına işaret etmektedir. Faktör yüklerinin yanı sıra, Açıklanan Ortalama Varyans (AOV) değerleri incelenerek yakınsak geçerliğin sağlanıp sağlanmadığı belirlenebilir. AOV'un .50'nin üzerinde olması yakınsak geçerliğin sağlandığına yönelik bir kanıt olarak görülmektedir (Fornell ve Larcker, 1981). Tablo 6'da DFA'dan elde edilen faktör yükleri için AOV değerleri görülmektedir.

Tablo 6. Helikopter Anne Ölçeğine ait DFA'dan elde edilen faktör yükleri için AOV değerleri

\begin{tabular}{lc}
\hline Boyut & DFA'ya Göre AOV Değerleri \\
\hline EAKH & .52 \\
AOYKH & .54 \\
TGYBKH & .53 \\
DYKH & .51 \\
\hline
\end{tabular}

Tablo 5'teki bulgular incelendiğinde, DFA'dan elde edilen faktör yükleri için hesaplanan AOV değerlerinin .50 ölçütünün altında olduğu görülmektedir. Iraksak geçerlik incelenirken, her boyut için AOV'un karekökünün alınmasıyla elde edilen değerin, söz konusu boyutun diğer boyutları ile arasındaki korelasyondan yüksek ve .50 ölçütünün üzerinde olması şartı aranmaktadır (Fornell ve Larcker, 1981). Tablo 7'de yer alan boyutlar arasındaki korelasyon ve her bir boyuta ait AOV için elde edilen karekök değerleri sunulmuştur. 
Tablo 7. Helikopter Anne Ölçeğine ait boyutlar arasındaki korelasyonlar ve her bir boyut için elde edilen karekök AOV değerleri

\begin{tabular}{|c|c|c|c|c|}
\hline & EAKH & AOYKH & TGYBKH & DYKH \\
\hline EAKH & 0.61 & & & \\
\hline AOYKH & $.487^{* *}$ & 0.65 & & \\
\hline TGYBKH & $.423^{* *}$ & $.466^{* *}$ & 0.64 & \\
\hline DYKH & $.437^{* *}$ & $.457^{* *}$ & $.377^{* *}$ & 0.66 \\
\hline
\end{tabular}

$* * \mathrm{p}<.01$

Tablo 7'deki bulgular incelendiğinde, her boyut için hesaplanan karekök AOV değerinin, söz konusu boyutun diğer boyutlar ile arasındaki korelasyondan yüksek ve .50 ölçütünün üzerinde olduğu görülmektedir.

\section{Helikopter Anne Ölçeğine Ait Güvenirlik Bulguları}

Helikopter anne ölçeğine ait güvenirliği iç tutarll1ık (Cronbach Alfa) ve bileşik güvenirlik (composite reliability) yöntemleriyle hesaplanmıştır. Bileşik güvenirlik, DFA'dan elde edilen faktör yükleri ve standart hata değerlerine dayalı olarak elde edilen bir iç tutarlık katsayısı olarak ifade edilmektedir. Güvenirlik katsayısı .70 ve üzerinde olan ölçeklerin güvenilir olduğu kabul edilmektedir (Büyüköztürk, 2010; Urbina, 2004).

Tablo 8. Helikopter Anne Ölçeğine ait güvenirlik değerleri

\begin{tabular}{lcc}
\hline Alt Ölçekler & İç Tutarlık & Bileşik Güvenirlik \\
\hline EAKH & .82 & .87 \\
AOYKH & .83 & .78 \\
TGYBKH & .79 & .80 \\
DYKH & .80 & .72 \\
Ölçeğin Tamamı İçin & .85 & .93 \\
\hline
\end{tabular}

Tablo 8 incelendiğinde tüm değerlerin .70'den büyük olduğu görülmektedir. Bu durum helikopter anne ölçeğinin iç tutarlık özelliği yönünden yeterli güvenirlik düzeyine sahip olduğunu göstermektedir.

\section{Helikopter Baba Ölçeğine Ait Geçerlik Bulguları}

Verilerin faktör analizine uygunluğu Kaiser-Mayer-Olkin (KMO) katsayısı ve Barlet Testi ile incelenmiştir. KMO'nun 0.60'dan yüksek çıkması ve Barlett testinin anlamlı çıkması gerekmektedir. Aksi taktirde analize devam edilemeyecektir. Faktör analizine başlarken verilerin uygunluğunu test etmek amacıyla yapılan Kaiser-Mayer-Olkin (KMO) katsayısı değeri 0,89 Bartlett's değeri ise $8118,453$ ( $\mathrm{p}<.000)$ olarak çıkması verilerin AFA ya uygun olduğunu göstermektedir. 
Ölçeğin baba formu için maddelerin faktör yük değeri asgari büyüklügünün kesme noktası .32 olarak belirlenmiştir. Bu çalışmada dik döndürme analizlerinden Varimax kullanılmış ve öz değerleri 1 'in üzerinde olan ve açıkladığı varyans $\% 5$ 'in üzerinde olan 4 faktörlü yapıda olmasına karar verilmiştir. Faktör yük değeri .32 altında olan ve binişik-bulaşık olan 4 madde çıkartılarak 21 maddelik varyansın \%45,88’ini açıklayan bir yapı elde edilmiştir.

Tablo 9. Helikopter Baba Ölçeği maddelerin faktörlere dağılımı ve açıkladıkları varyans yüzdeleri

\begin{tabular}{lllll}
\hline Maddeler & 1.Boyut & 2.Boyut & 3.Boyut & 4.Boyut \\
\hline HB15 & .814 & & & \\
HB20 & .747 & & & \\
HB23 & .714 & & & \\
HB10 & .699 & & & \\
HB5 & .661 & & & \\
HB25 & .620 & .839 & & \\
\hline HB14 & .834 & & \\
HB9 & .752 & & \\
HB24 & .714 & .816 & .771 \\
HB19 & .654 & .756 & .7968 \\
HB4 & & .687 & .763 \\
\hline HB22 & & .625 & \\
HB16 & & & \\
HB21 & & & & \\
HB3 & & & & \\
HB6 & & & & \\
HB1 & & & \\
HB2 & & & \\
HB7 & & & \\
HB17 & & & & \\
HB11 & & & & \\
\hline
\end{tabular}

Bu dört alt boyutun isimlendirilmesinde faktörlerde toplanan maddelerin içeriği dikkate alınmıştır. Birinci faktörde bulunan maddeler (HB15, HB20, HB23, HB10, HB5 ve HB25) daha çok babaların etik ve ahlaki konulardaki çocuk yetiştirme yaklaşımını yansıttığ için, bu boyuta "etik ve ahlaki konularda helikopterlik $(\mathrm{EAKH})$ ismi verilmiştir. Bu faktör altında toplanan maddeler annelerin çocuklarının ahlaki konulardaki davranışlarına karşı gösterdikleri tutum ve anlayışlarını yansıtmaktadır ve 6 maddenin faktör yükleri .81 ile .62 arasında değişmektedir.

İkinci faktörde bulunan maddeler (HB14, HB9, HB24, HB19, HB4) babaların, çocuğun okul hayatı ve akademik yaşamı ile ilgili konularda sergilediği tutum ile ilgili olduğu için, bu boyuta "akademik / okul yaşamı konularında helikopterlik (AOYKH) ismi verilmiştir. Bu boyutta yer alan 5 maddenin faktör yükleri .84 ile .65 arasında değişmektedir.

Üçüncü faktörde bulunan maddeler (HB22, HB16, HB21, HB3, HB6 ve HB1) babaların, çocuklarının temel yaşam becerileri ve güven konularına ilişkin olduğu için, bu boyuta "temel güven 
ve yaşam becerileri konusunda helikopterlik" (TGYBKH) ismi verilmiştir. Bu boyutta yer alan 6 maddenin faktör yükleri .81 ile .62 arasında değişmektedir.

Dördüncü faktörde bulunan maddeler (HB2, HB7, HB17 ve HB11) daha çok babaların, çocuklarının duygusal yaşamına ve mahremiyet alanlarına ilişkin tutumlarını yansıttığı için, “duygusal-kişisel yaşam alanında helikopterlik” (DYKH) ismi verilmiştir. Dört maddeden oluşan boyutta faktör yükleri .87 ile .73 arasında değişmektedir.

Tablo 10. Helikopter Baba Ölçeği faktörlerin açıkladıkları varyanslar

\begin{tabular}{|c|c|c|c|}
\hline Faktörler & Total & \% Açıkladıkları varyans & Kümülatif varyans \% \\
\hline 1 & 5.227 & 24.889 & 24.889 \\
\hline 2 & 1.732 & 8.250 & 33.138 \\
\hline 3 & 1.434 & 6.831 & 39.969 \\
\hline 4 & 1.242 & 5.914 & 45.883 \\
\hline 5 & .989 & 4.710 & 50.593 \\
\hline 6 & .855 & 4.072 & 54.665 \\
\hline 7 & .842 & 4.009 & 58.674 \\
\hline 8 & .810 & 3.859 & 62.533 \\
\hline 9 & .795 & 3.788 & 66.321 \\
\hline 10 & .725 & 3.451 & 69.772 \\
\hline 11 & .697 & 3.319 & 73.091 \\
\hline 12 & .675 & 3.213 & 76.304 \\
\hline 13 & .665 & 3.165 & 79.469 \\
\hline 14 & .634 & 3.018 & 82.487 \\
\hline 15 & .616 & 2.933 & 85.420 \\
\hline 16 & .599 & 2.851 & 88.271 \\
\hline 17 & .556 & 2.648 & 90.919 \\
\hline 18 & .527 & 2.511 & 93.430 \\
\hline 19 & .513 & 2.442 & 95.872 \\
\hline 20 & .462 & 2.198 & 98.070 \\
\hline 21 & .405 & 1.930 & 100.000 \\
\hline
\end{tabular}

\section{Algılanan Helikopter Baba Tutum Ölçeğine (HB) Ait Doğrulayıcı Faktör Analizi}

Algılanan helikopter baba tutum ölçeğine ait doğrulayıcı faktör analizi sonucu Şekil 2'de gösterilmiştir 


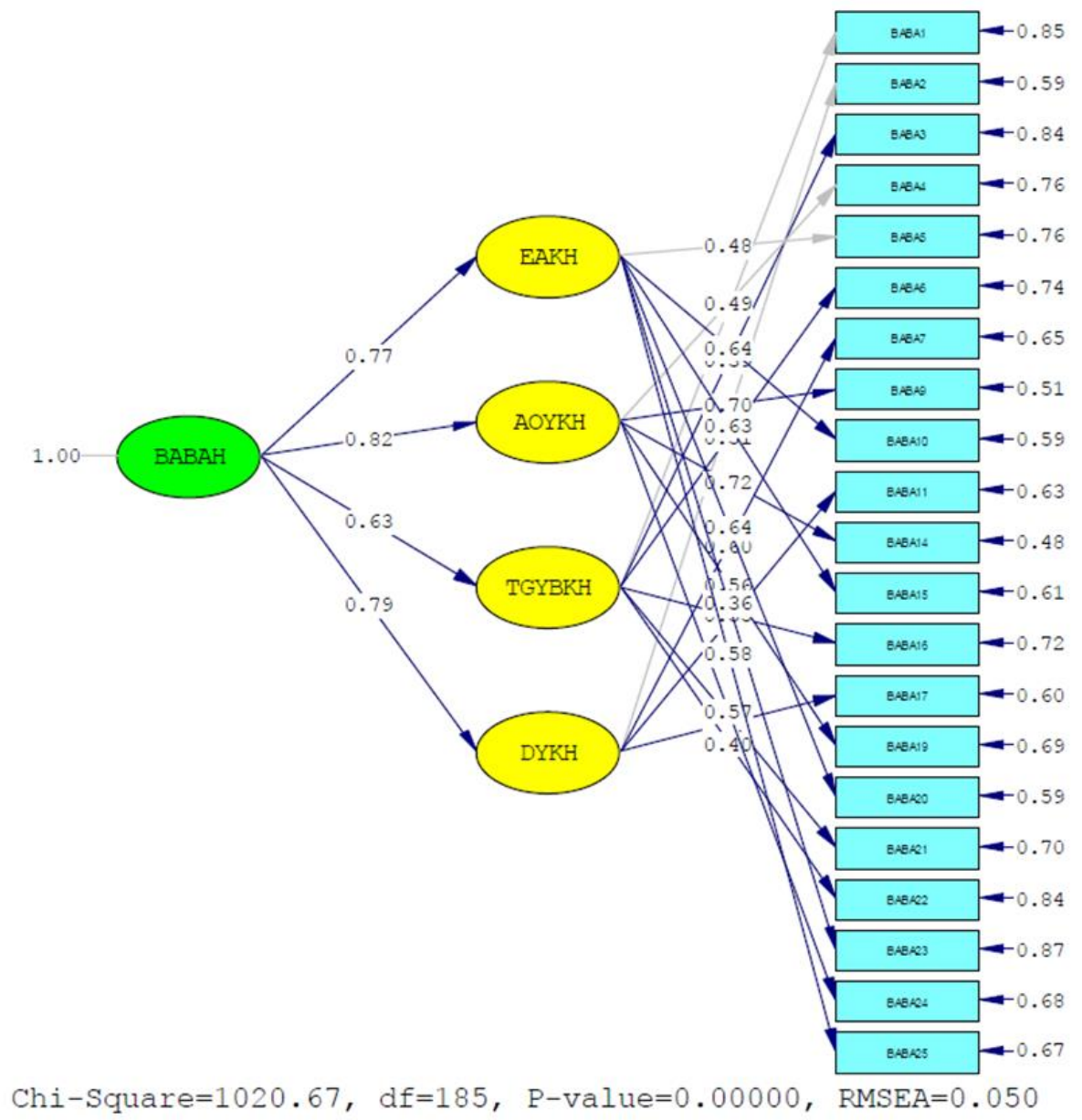

Şekil 2: Helikopter Baba Ölçeğine Ait Doğrulayııı Faktör Analizi

Anlamlılık değeri olan $p$, beklenen kovaryans matrisi ile gözlenen kovaryans matrisi arasındaki farkın (değerinin) manidarlı̆̆ı hakkında bilgi verir. DFA'da p değerinin anlamlı olması beklenir (Çokluk, Şekercioğlu ve Büyüköztürk, 2010). Şekil 2 incelendiğinde $p=.000 ; p<.05$ olarak elde edildiği görülmektedir. Bu durumda, beklenen kovaryans matrisi ile gözlenen kovaryans matrisi arasındaki fark anlamlıdır. Modele ilişkin uyumluluk indeksleri Tablo 11'de verilmiştir.

Tablo 11. Algılanan Helikopter Baba Tutum Ölçeği doğrulayıc1 faktör analizine ilişkin bulgular

\begin{tabular}{lllllllrrr}
\hline$\chi^{2}$ & sd & $\chi^{2} / \mathbf{s d}$ & RMSEA & SRMR & CFI & NFI & NNFI & GFI & AGFI \\
\hline 1020.67 & 185 & 5.51 & 0.050 & 0.045 & 0.96 & 0.95 & 0.95 & 0.95 & 0.94 \\
\hline
\end{tabular}

Tablo 11 incelendiğinde Ki-kare $\left(\mathrm{X}^{2}\right)$ uyum oranın 5,51 olarak bulunduğu görülmektedir. Daha önce de açıklandığı gibi, büyük örneklemlerde sd'nin büyümesi uyumun değerlendirilmesinde sorunlar çıkarmaktadır. Serbestlik derecesi arttıkça $\mathrm{X}^{2}$ ve sd oranı da artmaktadır. Böyle durumlarda diğer uyum indekslerine bakılarak karar verilebilir. Algılanan Helikopter Baba Tutum Ölçeğinin diğer uyum indeksleri (RMSEA $=0.050, p<.10 ; \mathrm{CFI}=0.96$, mükemmel uyum; $\mathrm{NFI}=0.95$, iyi uyum; 
GFI $=0.95$, iyi uyum; SRMR $=0.045$, iyi uyum) genel olarak değerlendirildiğinde modeli veriye iyi uyum gösterdiği söylenebilir. Diğer bir ifade ile Algılanan Helikopter Baba Tutum Ölçeği için modelin doğrulandığ1 ve yapı geçerliliğinin sağlandığı söylenebilir.

\section{Algılanan Helikopter Baba Tutum Ölçeği Yakınsak ve Iraksak Geçerlik}

Araştırmada HB ölçeğinin yapı geçerliğini incelemek için DFA'ya ek olarak, yakınsak ve ıraksak geçerlik çalışmalarına da yer verilmiştir. DFA'dan elde edilen faktör yüklerinin yeterince yüksek olması, ölçeğin yakınsak geçerliğinin sağlandığına işaret etmektedir. Faktör yüklerinin yanı sıra, Açıklanan Ortalama Varyans (AOV) değerleri incelenerek yakınsak geçerliğin sağlanıp sağlanmadığı belirlenebilir. AOV'un .50'nin üzerinde olması yakınsak geçerliğin sağlandığına yönelik bir kanıt olarak görülmektedir. Tablo 12'de DFA'dan elde edilen faktör yükleri için AOV değerleri görülmektedir.

Tablo 12. Helikopter Baba Ölçeğine ait DFA'dan elde edilen faktör yükleri için AOV değerleri

\begin{tabular}{lc}
\hline Boyut & DFA'ya Göre AOV Değerleri \\
\hline EAKH & .54 \\
AOYKH & .56 \\
TGYBKH & .51 \\
DYKH & .53 \\
\hline
\end{tabular}

Tablo 12'deki bulgular incelendiğinde, DFA'dan elde edilen faktör yükleri için hesaplanan AOV değerlerinin .50 ölçütünün üstünde olduğu görülmektedir.

Iraksak geçerlik incelenirken, her boyut için AOV'un karekökünün alınmasıyla elde edilen değerin, söz konusu boyutun diğer boyutları ile arasındaki korelasyondan yüksek ve .50 ölçütünün üzerinde olması şartı aranmaktadır. Tablo 13'de boyutlar arasındaki korelasyon ve her bir boyuta ait AOV için elde edilen karekök değerleri gösterilmiştir.

Tablo 13. Boyutlar arasındaki korelasyonlar ve her bir boyut için elde edilen karekök AOV değerleri

\begin{tabular}{lcccc}
\hline & EAKH & AOYKH & TGYBKH & DYKH \\
\hline EAKH & $\mathbf{0 . 5 6}$ & & & \\
AOYKH & $.463^{* *}$ & $\mathbf{0 . 6 1}$ & & \\
TGYBKH & $.922^{* *}$ & $.536^{* *}$ & $\mathbf{0 . 4 6}$ & $\mathbf{0 . 6 2}$ \\
DYKH & $.454^{* *}$ & $.475^{* *}$ & $.496^{* *}$ & \\
\hline
\end{tabular}

${ }^{* *} \mathrm{p}<0.01$.

Tablo 13'deki bulgular incelendiğinde, her boyut için hesaplanan karekök AOV değerinin, söz konusu boyutun diğer boyutlar ile arasındaki korelasyondan yüksek ve .50 ölçütünün üzerinde olduğu görülmektedir. Sadece TGYBKH boyutunda 0,50’nin biraz altında değer hesaplanmıştır.

\section{Algılanan Helikopter Baba Tutum Ölçeğine Ait Güvenirlik Bulguları}

Erken Çocukluk Çalışmaları Dergisi Cilt $3 \cdot$ Say1 $1 \cdot$ Mart
2019

Journal of Early Childhood Studies

Volume $3 \cdot$ Issue $1 \cdot$ March 
Algılanan Helikopter Baba Tutum Ölçeğine ait güvenirliği iç tutarlılık (Cronbach Alpha) ve bileşik güvenirlik (composite reliability) yöntemleriyle hesaplanmıştır. Bileşik güvenirlik, DFA'dan elde edilen faktör yükleri ve standart hata değerlerine dayalı olarak elde edilen bir iç tutarlık katsayısı olarak ifade edilmektedir.

Tablo 14. Algılanan Helikopter Baba Tutum Ölçeğine ilişkin güvenirlik değerleri

\begin{tabular}{lcc}
\hline \multicolumn{1}{c}{ Alt Ölçekler } & İç Tutarlık & Bileşik Güvenirlik \\
\hline EAKH & .83 & .79 \\
AOYKH & .78 & .74 \\
TGYBKH & .83 & .77 \\
DYKH & .76 & .71 \\
Ölçeğin Tamamı İçin & .83 & .90 \\
\hline
\end{tabular}

DFA'dan elde edilen faktör yükleri ve standart hata değerlerinden yola çıkılarak hesaplanmıştır. Güvenirlik katsayısı .70 ve üzerinde olan ölçeklerin güvenilir olduğu kabul edilmektedir (Büyüköztürk, 2010; Urbina, 2004).

\section{Algılanan Helikopter Ebeveyn Tutum Ölçeği (HA-HB) Uyum Geçerliği Sonuçları}

Geliştirilen Algılanan Helikopter Ebeveyn Tutum Ölçeğinin uyum geçerliğini sinamak amacıyla Çelik ve Öziş (2016) tarafindan geliştirilen Ebeveyn İlişki Tutumu Algısı Ölçeği ve Lamborn ve arkadaşları (1991) tarafindan geliştirilen, Yılmaz (2000) tarafından Türkçeye uyarlanan Anne Baba Tutum Ölçeği (ABTÖ) kullanılmıştır. Her iki ölçek, 186 kişilik üniversite öğrenci grubuna, helikopter ebeveyn ölçeği ile birlikte uygulanmış ve puanlar üzerinde korelasyon hesaplaması yapılmıştır. Bu konuda elde edilen sonuçlar Tablo 15'de gösterilmiştir.

Tablo 15. Algılanan Helikopter Ebeveyn Tutum Ölçeği uyum geçerliğine ilişkin korelasyon sonuçları

\begin{tabular}{llcc}
\hline & & \multicolumn{2}{c}{ Helikopter Ebeveyn Ölçeği } \\
\cline { 3 - 4 } & & Helikopter Anne (HA) & Helikopter Baba (HB) \\
\hline Ebeveyn İlişki Tutumu Alg1sı Ölçeği & & $.87^{* *}$ & $.69^{*}$ \\
& Otoriter & $-.76^{* *}$ & $-.88^{* *}$ \\
& İlgisiz & $.93^{* *}$ & $.69^{*}$ \\
& Koruyucu & -.09 & -.14 \\
& Demokratik & $.75^{* *}$ & $.38^{*}$ \\
\hline Anne Baba Tutum Ölçeği (ABTÖ) & Bağıml & & -.11 \\
& & -.21 & $-.91^{* *}$ \\
& Demokratik & $-.88^{* *}$ & $.69^{* *}$ \\
& İhmalkâr & $.79^{* *}$ & $-.54^{* *}$ \\
\hline$* * \mathrm{p}<.001$ & Otoriter & $-.45^{*}$ &
\end{tabular}

Tablo 15 incelendiğinde, özellikle “ebeveyn ilişki tutum alg1sı ölçeği”nin ilgisiz ebeveyn tutumu ve ABTÖ’nün ibmalkâr ve hosgörülü alt boyutları ile HA ve HB arasında negatif ve anlamlı ilişkinin gözlenmesi önemli bir bulgudur. Bu bulgu, helikopter ebeveyn ölçeğinin uyum geçerliği için 
önemeli bir kanıt olarak değerlendirilmiştir. Aynı zamanda bu bulgu, helikopter ebeveynlerin ilgisiz, ihmalkâr ve hoşgörülü olmadıklarını göstermesi bakımından da önemlidir. Bunun yanında; ebeveyn ilişki tutum algısı ölçeğì"nin otoriter, koruyucu ve bağımlı alt boyutları ile HA ve HB arasında pozitif yönde anlamlı ilişkinin bulunması da uyum geçerliğinin bir başka kanıtıdır. Ana Baba Tutum ölçeğinin otoriter tutum alt boyutu ile HA ve HB arasında da pozitif, anlamlı ve yüksek ilişkinin gözlenmesi, aynı şekilde uyum geçerliği için bir kanıt olarak değerlendirilmelidir. Uyum geçerliği amaçlı kullanılan her iki ölçekte de yer alan demokratik tutum alt boyutu ile HA ve HB arasında ise anlamlı bir ilişki bulunmamıştır. Gözlenen bu durum, helikopter ebeveynlerin demokratik olup olmadıkları konusunda bir fikir veremeyeceğimiz anlamına gelmektedir.

\section{SONUÇ ve TARTIŞMA}

Dünyada ne kadar anne-baba varsa o kadar farklı anne-baba tutumu vardır. Ancak tüm anne baba tutumlarını sevgi ve disiplin temelinde değerlendirmek mümkündür. Çünkü ailede çocuk eğitiminin iki temel kavramı sevgi ve disiplindir. Herhangi bir anne baba disiplin ve sevgi çizgisinin herhangi bir noktasında yer alır. Bu çizgi üzerinde tutumlar marjinal uçlara yaklaştıkça sağlıksızlaşır ve sorunlar başlar. Sağlıksız tutumların sonuçları çocuğun gelecek hayatı üzerinde de önemli ölçüde belirleyicidir. Helikopter anne-baba tutumları, sevgi ve disiplin bileşenin marjinal uçlarının ortaya çıkardığı bir çocuk yetiştirme anlayışıdır

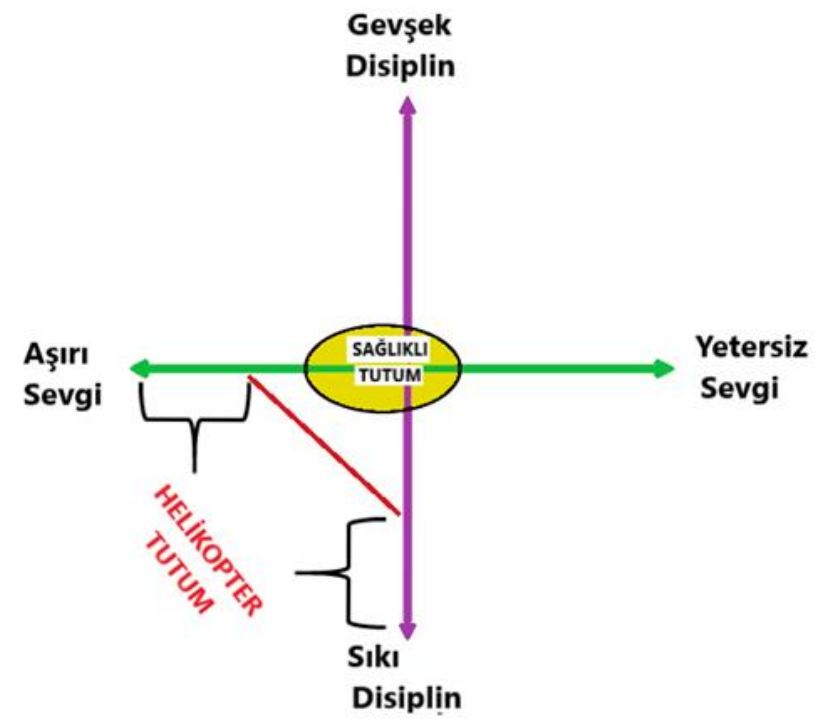

Şekil. Sevgi ve disiplin ekseninde helikopter ebeveyn tutumunun durumu (Y1lmaz, 2017)

Türkiye'de anne-baba tutumları konusunda çok sayıda araştırma yapılmış olmasına karşılık, özel olarak helikopter tutumu inceleyen bir araştırma yoktur. Genel anne baba tutumları 
araştırmalarında, "gevşek ya da başıboş tutum", ya da "sıkı disiplin" konuları alt boyutlar olarak ele alınmış olsa da bu araştırmalar helikopter ebeveyn tutumlarını açıklamaktan uzaktır.

Geliştirilen Helikopter Ebeveyn Tutum Ölçeği bu alanda ilk çalışmadır. Doğal olarak eleştirilmesi ve geliştirilmesi gerekmektedir. Bu çalışmanın en azından Ülkemizde helikopter anne baba tutumlarını, bilimsel platformda tartışmaya açması umulmaktadır.

Geliştirilen ölçek, istatistiksel anlamda pek çok şartı sağlamaktadır. Uyum endeklerinin biri dışında $\left(\mathrm{X}^{2} / \mathrm{sd}\right)$ diğer tüm uyum endeksleri yeterlidir ve yeterli geçerlik özelliğine sahip olduğuna işaret etmektedir. Örneklem büyüklüğünden kaynaklanan sebeplerden dolay1 (X2/sd) endeksi “iyi uyum” sınırlarının dışında sonuç vermiştir. Ölçeğin farklı örneklemlerde sınanması ile bu konuda daha güvenilir sonuçlar elde edilebilir.

Geliştirilen ölçeğin ölçtüğ̈̈ özellik algılanan helikopter ebeveyn tutumları ile sinırlıdır ve Türkiye'deki ilk çalışmadır. Bu haliyle farklı yaş gruplarında uygulanıp sonuçların bilimsel platformlarda tartışılması bu konunun gelişimine katkı sağlayacaktır. Ölçek kullanılarak helikopter ebeveynliğin çeşitli boyutları ve sonuçları ortaya çıkarılabilir. Örneğin, helikopter ebeveynlik anlayışı ile psikopatoloji, ya da pozitif psikolojinin kavramları ile helikopter tutum arasında ilişkiler aranabilir.

\section{KAYNAKÇA}

BaoChun, Z. H., (2016). Conceptualization, measurement, and effects of helicopterparenting on college students from the millennial generation. Yayımlanmamış Doktora Tezi, Western Michigan Üni\&rsitesi, Counselor Education and Counseling Psychology Bölümü, ABD https://scholarworks.wmich.edu/dissertations/1956

Bradley-Geist J., \& Olson-Buchanan J. (2014) Helicopter parents: An examination of the correlates of over-parenting of college students, Education Training, 56(4), 314-328. https://doi.org/10.1108/ET-10-2012-0096

Büyüköztürk, Ş. (2010). Sosyal bilimler için veri analiæ̧i el kitabı, Ankara: Pegem Akademi Yayıncıllk

Cono\&r, K., \& Daiute, C. (2017). The process of self-regulation in adolescents: A Narrative approach. Journal of Adolescence, 57, 59-68. https://doi.org/10.1016/j.adolescence.2017.03.006

Çelik, E., \& Öziş, G. (2016). Ebeveyn İlişki Tutumu Algısı Ölçeğinin geliştirilmesi ve psikometrik özelliklerinin incelenmesi. Cumburiyet International Journal of Education-CIJE, 5(2), 50-64. 
Çokluk, Ö., Şekercioğlu, G., \& Büyüköztürk, Ş. (2010). Sosyal bilimler için çok değişsenli istatistik SPSS \& LISREL uygulamalar. Ankara: PegemA Akademi Yayınevi.

Davis, L.L. (1992). Instrument review: Getting the most from a panel of experts. Applied Nursing Research, 5, 194-197.

Fan, X., Thompson, B., \& Wang, L. (1999). Effects of sample size, estimation methods, and model specification on structural equation modelling fit indexes, Structural Equation Modelling, 6(1), 56-83.

Farley, J. P., \& Kim-Spoon, J. (2014). The development of adolescent self-regulation: Reviewing the role of parent, peer, friend, and romantic relationships. Journal of Adolescence, 37(4), 43340. https://doi.org/10.1016/j.adolescence.2014.03.009

Findley, D., \& Ojanen, T. (2013). Agentic and communal goals in early adulthood: Associations with narcissism, empathy, and perceptions of self and others. Self and Identity, 12, 504-526. https://doi.org/10.1080/15298868.2012.694660

Fingerman, K. L., Cheng, Y., Wesselmann, E. D., Zarit, S., Furstenberg, F., \& Birditt, K. S. (2012), Helicopter parents and landing pad kids: Intense parental support of grown children. Journal of Marriage and Family, 74, 880-896. https://doi.org/10.1111/j.1741-3737.2012.00987.x

Fischer, J. L., Forthun, L. F., Pidcock, B. W., \& Dowd, D. A. (2007). Parent relationships, emotion regulation, psychosocial maturity and college student alcohol use problems. Journal of Youth and Adolescence, 36, 912-926. https://doi.org/10.1007/s10964-006-9126-6

Fornell, C., \& Larcker, D.F. (1981). Evaluating structural equation models with unobservable variables and measurement error. Journal of Marketing Research, 48, 39-50. DOI: $10.2307 / 3151312$

Gui, T., \& Koropeckyj-Cox, T. J. (2016). "I Am the Only Child of my Parents:” Perspectives on future elder care for parents among Chinese only-children living overseas. Journal of CrossCultural Gerontology, 31(3), 255-275. https://doi.org/10.1007/s10823-016-9295-z

Hesse, C., Mikkelson, A.C., \& Saracco, S. (2017) Parent-child affection and helicopter parenting: Exploring the concept of excessi\& affection, Western Journal of Communication, 82(4), 457474. https://doi.org/10.1080/10570314.2017.1362705

Hooper, D., Coughlan, J., \& Mullen, M. (2008). Structural equation modelling: Guidelines for determining model fit. Electronic Journal of Business Research Methods, 6(1), 53-60. http://arrow.dit.ie/libart/4

Hu, L.T., \&Bentler, P.M. (1999). Cutoff criteria for fit indexes in covariance structure analysis: con\&ntional criteria \&rsus new alternati\&s. Structural Equation Modeling, 6(1), 1-55.

Jöreskog, K. G., \& Sörbom, D. (1993). LISREL 8: Structural equation modeling with the SIMPLIS command language. Chicago, IL, US: Scientific Software International; Hillsdale, NJ, US: Lawrence Erlbaum Associates, Inc. 
Kalkan, M., \& Odac1, H. (2007). Psikolojik doğum sırası \& ana babaya bağlanma: Okul öncesi öğretmen adayları üzerine bir çalışma. E-Journal of New World Sciences Academy Education Sciences, 5(3), 810-819.

Stewart, A., Stewart, E. A., \& Campbell, L. F. (2001). The relationship of psychological birth order to the family atmosphere and to personality. The Journal of Individual Psychology, 57(4), 42-60.

Kelly, L., Duran, R.L., \& Miller-Ott, A. E. (2017) Helicopter parenting and cell-phone contact between parents and children in college. Southern Communication Joumal, 82(2), 102-114. https://doi.org/10.1080/1041794X.2017.1310286

Kline, R. B. (2005). Principle and practice of structural equation modelling. (Second Edition). New York: The Guilford Press.

Kouros, C.D., Pruitt, M. M., Ekas, N. V., Kiriaki, R., \& Sunderland, M. (2017). Helicopter parenting, autonomy support, and college students' mental health and well-being: The moderating role of sex and ethnicity. Journal of Child and Family Studies. 26(3), 939-949. https://doi.org/10.1007/s10826-016-0614-3

Kwon, KA., Yoo, G., \& Bingham, G.E. (2016). Helicopter parenting in emerging adulthood: Support or barrier for Korean college students' psychological adjustment? Journal of Child and Family Studies, 25(1), 136-145. https://doi.org/10.1007/s10826-015-0195-6

Kwon, KA., Yoo, G., \& De Gagne, J.C. (2017). Does culture matter? A Qualitative inquiry of helicopter parenting in Korean American college students. Journal of Child and Family Studies, 26(7), 1979-1990. https://doi.org/10.1007/s10826-017-0694-8

Lamborn, S. D., Mounts, N. S., Steinberg, L., \& Dornbusch, S. M. (1991). Patterns of competence and adjustment among adolescents from authoritative, authoritarian, indulgent, and neglectful families. Child De\&lopment, 62(5), 1049-1065. http://dx.doi.org/10.2307/1131151

LeMoyne, T., \& Buchanan, T. (2011). Does "Hovering" matter? Helicopter parenting and its effect on well-being. Sociological Spectrum, 31(4), 399-418. https://doi:10.1080/02732173.2011.574038

Lo\&, H. (2016). A New approach to measuring helicopter parenting: The multidimensional helicopter parenting scale. Theses and Dissertations. 583, p. 80. https://ir.library.illinoisstate.edu/etd/583

MacCallum, R. C., Widaman, K. F., Preacher, K. J., \& Hong, S. (2001). Sample size in factor analysis: The role of model error. Multivariate Behavioral Research, 36, 611-637.

McGinley, M. (2018). Can hovering hinder helping? Examining the joint effects of helicopter parenting and attachment on prosocial behaviors and empathy in emerging adults. The Journal of Genetic Psychology Research and Theory on Human Development, 179(2), 102-115. https://doi.org/10.1080/00221325.2018.1438985

Milita, K., \& Bunch, J. (2017). Helicopter parenting and the policy attitudes of college students. Political Science \& Politics, 50(2), 359-366. https://doi.org/10.1017/S1049096516002808 
Moilanen, K. L., \& Manuel, M. L. (2017). Parenting, self-regulation and social competence with peers and romantic partners. Journal of Applied Developmental Psychology, 49, 46-54. https://doi.org/10.1016/j.appdev.2017.02.003

Nelson, L.J., Padilla-Walker, L. M., \& Nielson, M. G. (2015). Is Hovering smothering or loving? An examination of parental warmth as a moderator of relations between helicopter parenting and emerging adults' indices of adjustment. Emerging Adulthood, 3(4), 282-285. https://doi.org/10.1177/2167696815576458

Odenweller, K. G., Booth-Butterfield, M., \& Weber, K. (2014) Investigating helicopter parenting, family environments, and relational outcomes for millennials, Communication Studies, 65(4), 407-425. https://doi.org/10.1080/10510974.2013.811434

Padilla-Walker, L.M., \& Nelson, l. J. (2012). Black hawk down? Establishing helicopter parenting as a distinct construct from other forms of parental control during emerging adulthood. Journal of Adolescence. 35(5), 1177-1190. https://doi.org/10.1016/j.adolescence.2012.03.007

Reed, K., Duncan, J.M., Lucier-Greer, M., Fixelle, C., \& Ferraro, A.J. (2016). Helicopter parenting and emerging adult self-efficacy: 1mplications for mental and physical health. Journal of Child and Family Studies, 25(10). 3136-3149. https://doi.org/10.1007/s10826-016-0466-x

Schiffrin, H. H., \& Miriam L. M. (2017). The effects of helicopter parenting on academic motivation. Journal of Child and Family Studies, 26(5), 1472-1480. https:// doi.org/10.1007/s10826-017-0658-z

Schiffrin, H. H., Liss, M., Miles-McLean, H., Geary, K. A., Erchull, M. J., \& Tashner, T. (2014). Helping or hovering? The effects of helicopter parenting on college students' well-being. Journal of Child and Family Studies, 23, 548-557. https://doi.org/10.1007/s10826-013-97163.

Schumacker, R.E., \& Lomax, R.G. (1996). A Beginner's Guide to Structural Equation Modelling. Mahwah, New Jersey: Lawrence Erlbaum Associates, Publishers.

Segrin, C., Woszidlo, A., Givertz, M., Bauer, A., \& Murphy, M. T. (2012). The association between over parenting, parent-child communication, and entitlement and adaptive traits in adult children. Family Relations 61(2), 237-252. https://doi.org/10.1111/j.17413729.2011.00689.x

Steiger, J.H. (1990), Structural model evaluation and modification. Multivariate Behavioral Research, 25, 214-12.

Şehribanoğlu, S. (2005). Yapısal eşitlik modelleri ve bir uygulaması. Yayımlanmamış yüksek lisans tezi, Yüzüncü Yıl Üni\&rsitesi Fen Bilimleri Enstitüsü Zootekni Anabilim Dalı, Van.

Tully, G. (2017). The relation of helicopter parenting to depressive symptomatology in emerging adults. A Thesis: Submitted to the Graduate Faculty of the University of South Alabama, ProQuest Dissertations Publishing: 10275303.

Ungar, M. (2009) Overprotective parenting: Helping parents provide children the right amount of risk and responsibility. The American Journal of Family Therapy, 37(3), 258-271. https://doi.org/10.1080/01926180802534247 
Urbina, S. (2004). Essentials of psychological testing. New Jersey: John Wiley \& Sons. Inc.

Van Ingen, D. J., Freiheit, S., Steinfeldt, J. A., \& Roberts, A. (2015). Helicopter parenting: The effect of an overbearing caregiving style on peer attachment and self-efficacy. Journal of College Counseling 18(1), 7-20. https:/ / doi:10.1002/j.2161-1882.2015.00065.x

Yaşlığlu, M. M. (2017). Sosyal bilimlerde faktör analizi ve geçerlilik: Keşfedici ve doğrulayıcı faktör analizlerinin kullanilmas1. Istanbul University Journal of the School of Business, 46, (Special Issue) $74-85$.

Yılmaz, A. (2000). Anne-Baba Tutum Ölçeğinin güvenirlik ve geçerlik çalışması. Cocuk ve Gençlik Ruh Sağglğ Dergisi, 7(3), 160-172.

Y1lmaz, H. (2017). Sevgili anne ve babacı̆̆m lütfen bu kitabı okur musun? Konya: Çizgi Kitapevi 


\section{Ek 1: Algılanan Helikopter Ebeveyn Tutum Ölçeği (AHETÖ)}

\begin{tabular}{|c|c|c|c|c|c|c|c|c|}
\hline \multicolumn{4}{|c|}{ ANNEM } & \multirow[b]{2}{*}{$\begin{array}{l}\text { Arkadaşlar kendi çocukluğunuzu hatırlamanızı, anne ve babanızın aşă̆ıda } \\
\text { sayılan tutum ve davranışlara sahip olup olmadıklarını düşünmenizi istiyorum. } \\
\text { Aşağıda yazılan davranış ve tutumları hem anneniz hem de babanız için ayrı ayrı } \\
\text { değerlendirerek cevaplayınız. }\end{array}$} & \multicolumn{4}{|c|}{$\mathbf{B A B A M}$} \\
\hline 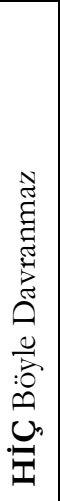 & 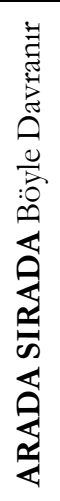 & 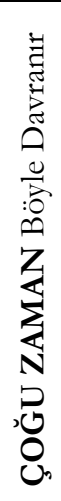 & 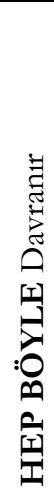 & & 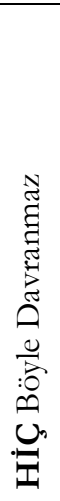 & 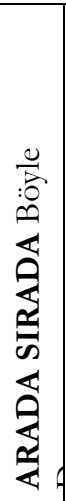 & 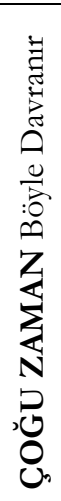 & 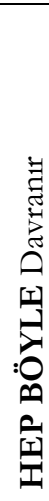 \\
\hline (1) & (2) & (3) & $(4)$ & 1- Her gün giyeceğim kıyafetleri seçmek isterdi. & (1) & (2) & (3) & $(4)$ \\
\hline (1) & $(2)$ & $(3)$ & $(4)$ & 2- Ne zaman üzgün olsam 1srarla "neyin var" diye sorardı. & (1) & (2) & (3) & $(4)$ \\
\hline (1) & (2) & (3) & (4) & 3- Arkadaşlarımla oyun oynarken oyunumuza müdahale etmeden duramazdı. & (1) & (2) & (3) & $(4)$ \\
\hline (1) & (2) & (3) & (4) & 4- Akşam eve geldiğimde ilk soruları genellikle okul hayatım ile ilgili olurdu. & (1) & (2) & (3) & $(4)$ \\
\hline (1) & $(2)$ & $(3)$ & $(4)$ & 5- Dünyanın ve çevremizin kötü insanlarla dolu olduğuna inanırdı. & (1) & (2) & $(3)$ & $(4)$ \\
\hline (1) & $(2)$ & $(3)$ & $(4)$ & 6-Okula başladığım günlerde saatlerce okul dışında veya evin önünde beni beklerdi. & $(1)$ & (2) & $(3)$ & $(4)$ \\
\hline (1) & $(2)$ & (3) & $(4)$ & 7- Suratımın asık olmasına hiç katlanamazdı. & (1) & $(2)$ & (3) & $(4)$ \\
\hline (1) & (2) & (3) & $(4)$ & 8- Sınav sonuçlarımın açıklanacağı zamanı sabırsızlıkla beklerdi. & (1) & (2) & (3) & $(4)$ \\
\hline (1) & (2) & (3) & (4) & 9- Çok s1k nasihat ederdi. & (1) & (2) & (3) & $(4)$ \\
\hline (1) & $(2)$ & (3) & $(4)$ & 10- Benim özel bir hayatım olabileceğini kabul etmek istemezdi. & (1) & (2) & (3) & $(4)$ \\
\hline (1) & (2) & (3) & (4) & 11- Okul notlarım için benden daha çok o kaygılanırdı. & (1) & (2) & (3) & $(4)$ \\
\hline (1) & $(2)$ & $(3)$ & $(4)$ & 12- Yüz kızartıcı bir davranışta bulunmamam konusunda çok nasihat ederdi. & (1) & (2) & (3) & $(4)$ \\
\hline (1) & $(2)$ & $(3)$ & $(4)$ & 13- Parkta ve sokakta gezerken asla elimi birakmak istemezdi. & (1) & $(2)$ & $(3)$ & $(4)$ \\
\hline$(1)$ & $(2)$ & $(3)$ & $(4)$ & 14- Duygularımı her zaman merak ederdi. & (1) & (2) & (3) & $(4)$ \\
\hline (1) & $(2)$ & (3) & $(4)$ & 15- Öğretmenim ile çok sık görüşmek isterdi. & (1) & $(2)$ & $(3)$ & $(4)$ \\
\hline (1) & (2) & (3) & $(4)$ & 16- Kötü huy ve alışkanlıklar edinmemden çok korkardı. & (1) & (2) & (3) & $(4)$ \\
\hline (1) & (2) & (3) & $(4)$ & 17-Bana yemek yedirmek için arkamdan koştururdu. & (1) & (2) & (3) & $(4)$ \\
\hline (1) & $(2)$ & (3) & $(4)$ & 18- Çantamın içini ve ceplerimi sık sık kurcalamaktan hoşlanırdı. & (1) & (2) & (3) & $(4)$ \\
\hline (1) & (2) & (3) & (4) & 19- Karşı cinsten bir arkadaşımın olması ihtimali onu endişelendirirdi. & (1) & (2) & (3) & $(4)$ \\
\hline (1) & (2) & (3) & $(4)$ & 20- Okul ödevlerim için benden çok o çaba gösterirdi. & (1) & (2) & (3) & $(4)$ \\
\hline (1) & $(2)$ & $(3)$ & $(4)$ & 21- Mükemmel bir insan olmamı isterdi. & (1) & $(2)$ & (3) & $(4)$ \\
\hline
\end{tabular}

\section{Ek 2: Helikopter Ebeveyn Tutum Ölçeği Puanlama ve Değerlendirme Yönergesi}

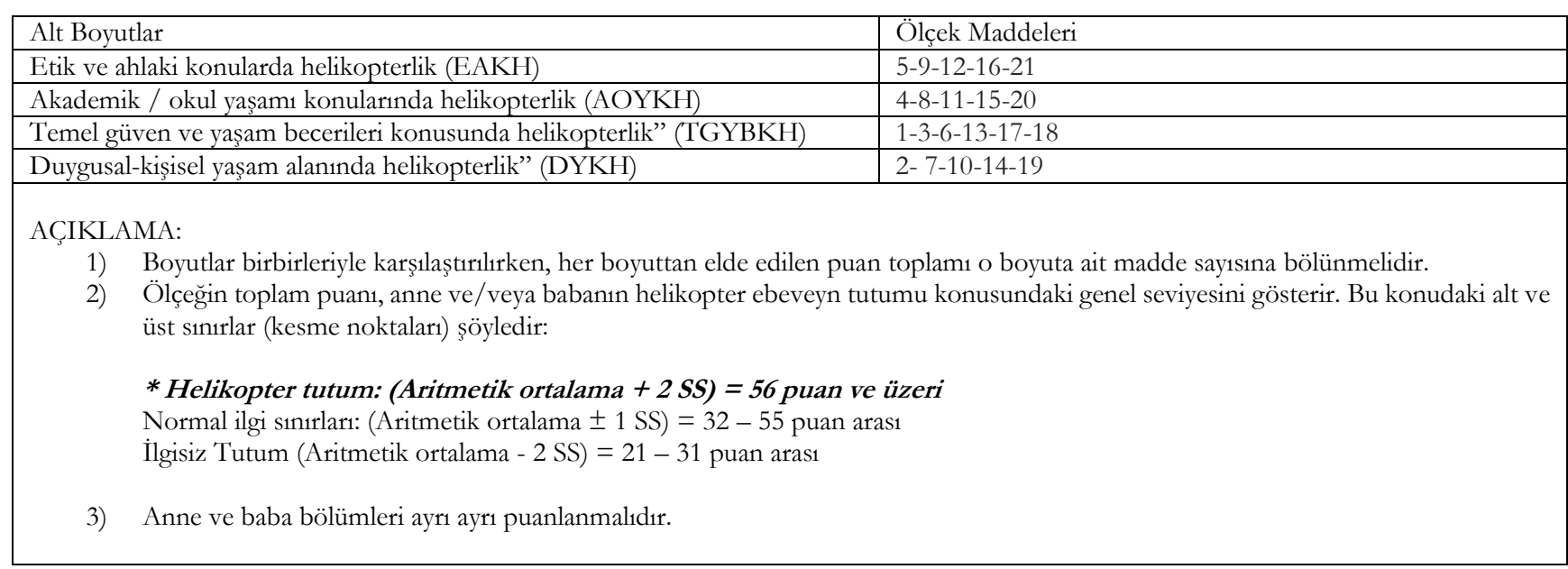

NOT: Bilimsel etik ve ilkelere bağh kalmak koşuluyla araştırmacı ve eğitimciler tarafindan kullanılması için iẓin alınmasına gerek yoktur. 